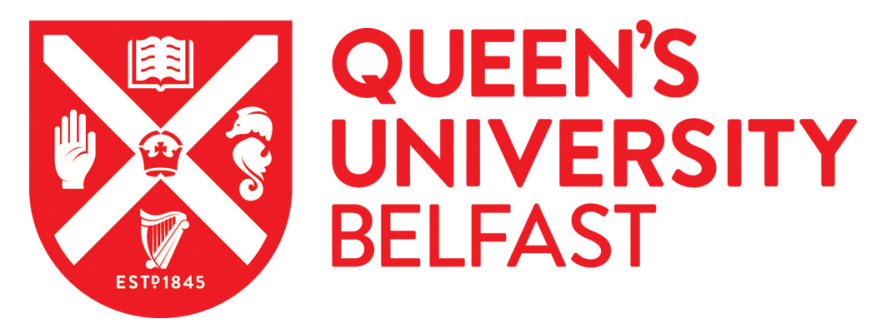

\title{
Does Basel Compliance Matter for Bank Performance?
}

Ayadi, R., Naceur, S. B., Casu, B., \& Quinn, B. (2016). Does Basel Compliance Matter for Bank Performance? Journal of Financial Stability, 23, 15-32. https://doi.org/10.1016/j.jfs.2015.12.007

Published in:

Journal of Financial Stability

Document Version:

Peer reviewed version

Queen's University Belfast - Research Portal:

Link to publication record in Queen's University Belfast Research Portal

Publisher rights

(c) 2016 Elsevier Ltd. This manuscript version is made available under the CC-BY-NC-ND 4.0 license http://creativecommons.org/licenses/bync-nd/4.0/which permits distribution and reproduction for non-commercial purposes, provided the author and source are cited.

\section{General rights}

Copyright for the publications made accessible via the Queen's University Belfast Research Portal is retained by the author(s) and / or other copyright owners and it is a condition of accessing these publications that users recognise and abide by the legal requirements associated with these rights.

Take down policy

The Research Portal is Queen's institutional repository that provides access to Queen's research output. Every effort has been made to ensure that content in the Research Portal does not infringe any person's rights, or applicable UK laws. If you discover content in the Research Portal that you believe breaches copyright or violates any law, please contact openaccess@qub.ac.uk. 


\title{
Does Basel Compliance Matter for Bank Performance?
}

\author{
Rym AYADI ${ }^{a}$, Sami BEN NACEUR ${ }^{b}$, \\ Barbara CASU ${ }^{c}$, Barry QUINN ${ }^{d}$
}

\begin{abstract}
The global financial crisis underscored the importance of regulation and supervision to a wellfunctioning banking system that efficiently channels financial resources into investment. In this paper, we contribute to the ongoing policy debate by assessing whether compliance with international regulatory standards and protocols enhances bank operating efficiency. We focus specifically on the adoption of international capital standards and the Basel Core Principles for Effective Bank Supervision (BCP). The relationship between bank efficiency and regulatory compliance is investigated using the Simar and Wilson (2007) double bootstrapping approach on an international sample of publicly listed banks. Our results indicate that overall BCP compliance, or indeed compliance with any of its individual chapters, has no association with bank efficiency.
\end{abstract}

JEL Classification Numbers: G21, G18, C24

Keywords: BCP, Efficiency, Regulatory Compliance

${ }^{a}$ Rym Ayadi, HEC Montréal (rym.ayadi@hec.ca); ${ }^{b}$ Sami Ben Naceur, International Monetary Fund (SBenNaceur@imf.org); ${ }^{\mathrm{C}}$ Barbara Casu, Cass Business School, City University London; b.casu@city.ac.uk; ${ }^{\mathrm{d}}$ Barry Quinn, Queen's Management School, Queen's University Belfast (b.quinn@qub.ac.uk). 


\section{INTRODUCTION}

In this paper, we assess whether compliance with international regulatory standards and protocols affects bank performance. We focus on the adoption of international capital standards and the Basel Core Principles for Effective Bank Supervision (BCP). These principles, issued in 1997 by the Basel Committee on Bank Supervision, have since become the global standards for bank regulation, widely adopted by regulators in developed and developing countries. The severity of the 2007-09 financial crisis has cast doubt on the effectiveness of these global standards to foster bank stability and regulatory reforms are under way in several countries. The initial crisis-induced assessment of regulatory failure is now giving way to a more complex regulatory dialogue and detailed evaluation of the principles underlying international regulatory standards as well as the implications of their adoption, in terms of banks' safety and soundness. In addition, the burden of compliance with international regulatory standards is becoming increasingly onerous, and financial institutions worldwide are developing compliance frameworks to enable management to meet more stringent regulatory standards. As regulators refine and improve their approach and methodologies, banks must respond to more stringent compliance requirements. This has implications for risk management and resource allocation, and, ultimately, on bank performance. ${ }^{1}$

The goal of this paper is to advance the existing literature by examining the relationship between the observance of international regulatory standards and the performance the banking sector. To evaluate bank performance we follow a structural approach, which relies on a model of the banking firm and a concept of optimization (Hughes and Mester, 2014). The traditional structural approach relies on the economics of cost minimization or profit maximization; bank technical or operating (in)efficiency is broadly defined as the distance between an actual production process and the "best practice" or the optimal standard. ${ }^{2}$

From a theoretical perspective, scholars' predictions as to the effects of regulation and supervision on bank performance are conflicting. Given the unresolved conflicting theoretical views on regulation and, hence, on supervision, in the aftermath of the 2007-09 financial crisis, at a time when significant regulatory reforms are under way, it is important to shed more light on the effects of the existing approach to regulation in general and, ultimately, to propose policy

\footnotetext{
${ }^{1}$ By the end of 2014, Citigroup had nearly 30,000 employees working on regulatory and compliance issues (an increase of 33 percent since 2011). This trend is compounded by the fact that compliance staffing is increasing at a time when the bank has been shrinking assets and staff (The Tell, Wall Street Journal, July 2014). Similarly, JPMorgan Chase expanded its risk control staff by 30 percent since 2011. In Europe, Deutsche Bank is doubling its compliance spending and adding at least 500 additional resources (Bloomberg, 9 July 2014). In 2013, HSBC announced plans to add approximately 3,000 compliance staff. This would bring its total compliance staff to more than 5,000, almost 2 percent of its global workforce, which has shrunk by over 40,000 in the past two years. (The Times, 25 September 2013).

${ }^{2}$ Traditionally, structural approaches to the evaluation of bank performance have assumed that all banks are equally efficient at either minimizing costs or maximizing profits, subject to a random error $\left(\varepsilon_{i}\right)$, which is assumed to be normally distributed. Alternatively, structural approaches rely on the estimation of a frontier to capture the best practice, and estimate inefficiency as the difference between the best practice performance and the actual performance. In this study we follow the latter. There are four main methodologies for estimating the frontier: stochastic frontier; the distribution-free approach; the thick frontier and data envelopment analysis (see Hughes and Mester (2014) for a detailed discussion of the relative merits of the different methodologies).
} 
avenues for improvements. Despite the fact that bank regulation and supervision have been a key focus of the post-crisis regulatory debate, there is no evidence that any common set of best practices is universally appropriate for promoting well-functioning banks. As a consequence, the question of how regulation affects bank performance remains unanswered. Regulators around the world are still grappling with the issue of what constitutes good regulation and which regulatory reforms they should undertake.

In this paper, we contribute to the ongoing policy debate by assessing whether compliance with international regulatory standards and protocols on supervision enhances banks' operating efficiency. We focus on regulatory compliance, because it can affect bank performance through several channels: (a) lending decisions; (b) asset allocation decisions; (c) funding decisions. Regulatory compliance is costly. Ultimately, these costs are borne not by regulators or banks, but by bank customers, in terms of lower saving rates and higher lending rates. This, in turn, may lead to an inefficient allocation of resources in the economy. As Haldane (2013) indicates, if systemic stability can be achieved in other ways, these are deadweight costs to society.

On the regulators' side, excessive reliance on systematic adherence to a checklist of regulations and supervisory practices might hamper regulators' monitoring efforts and prevent a deeper understanding of banks' risk-taking. More specifically, to shed some light on the aforementioned issues, we aim to answer the following questions: (i) Does compliance with international regulatory standards affect bank operating efficiency? (ii) By what mechanisms does regulatory compliance affect bank performance? (iii) To what extent do bank-specific and country-specific characteristics soften or amplify the impact of regulatory compliance on bank performance? (iv) Does the impact of regulatory compliance increase with level of development?

Building on the IMF and the World Bank Basel Core Principles for Effective Bank Supervision (BCP) assessments conducted from 1999 to 2014, we evaluate how compliance with BCP affects bank performance for a sample of 1,146 publicly listed banks drawn from a broad cross-section of countries. We focus on publicly listed banks, on the assumption that these institutions are subject to more stringent regulatory controls and compliance requirements. This focus should also enhance cross-country comparability because these banks share internationally adopted accounting standards. Furthermore, we categorize the sample countries by both economic development and geographic region. Following Demirgüç-Kunt and Detragiache (2011), to assess the level of bank compliance we use an aggregate BCP compliance score and a disaggregated approach, to differentiate among various dimensions of regulation and supervision. To measure bank performance we begin with the estimation of a common global frontier by means of Data Envelopment Analysis (DEA), a widely used nonparametric methodology. Unlike previous studies, we explicitly account for cross-country heterogeneity in bank efficiency analysis, by adopting a two-stage double bootstrapping procedure: the first stage produces (bias-corrected) efficiency estimates which are then used in the second-stage truncated regressions to infer how various (bank-specific and country-specific) factors influence the (biascorrected) estimated efficiency (Simar and Wilson, 2007). Earlier studies suggest that the impact of regulation and supervision increases with the level of development (Barth et al., 2004; Demirgüç-Kunt et al., 2008). To assess whether regulatory compliance affects banks differently 
in countries at different levels of development, we re-run the estimations focusing on a subsample of emerging markets.

Our results indicate that overall BCP compliance-or indeed compliance with any of the individual chapters - has no association with bank operating efficiency. This result holds after controlling for bank-specific characteristics, the macroeconomic environment, institutional quality, and the existing regulatory framework. It adds further evidence to the argument that compliance per se has little effect on bank efficiency. Conditional on being a good bank (that is, a bank complying international regulatory and supervisory standards) regulation has no impact on bank performance. Nevertheless, increasing regulatory constraints may prevent banks from efficient allocation of resources. When only banks in emerging and developing countries are considered, a relationship is revealed. The extent of ongoing supervision is negatively associated with input efficiency. On the other hand, the extent to which supervisors apply international global standards is positively associated with bank input efficiency. This difference indicates that in emerging markets, adherence to international standards of best practice may have a positive effect on bank performance. However, these results need to be treated with caution, because they may also reflect the inability of assessors to provide a consistent cross-country evaluation of effective banking regulation.

The remainder of the paper is organized as follows: Section 2 presents a review of the relevant literature. Section 3 presents the data and the methodology; Section 4 contains the results, and Section 5 concludes.

\section{Literature REVIEW}

Financial regulation and supervision are considered key to financial stability as a well functioning regulatory and supervisory framework can help minimize moral hazard and discourage excessive risk-taking. Post crisis, questions were raised about the appropriateness of the existing regulatory setting, with a number of studies indicating weaknesses in regulation and supervision as one of the key causes of the severity of the crisis (Cihak et al, 2013; Merrouche and Nier 2014). While efforts to strengthen regulation and supervision are well under way in many countries, there is no evidence that any common set of rules is universally appropriate for promoting well performing and safe banks. Regulatory structures that will succeed in some countries may not constitute best practice in other countries that have different institutional settings. As pointed out by Barth et al, (2013), there is no broad cross-country evidence as to which of the many different regulations and supervisory practices employed around the world work best to promote financial stability. Regulators are still grappling with the question of what constitutes good regulation and which regulatory reforms they should undertake. A recent review of the FSAP program (IMF, 2014) includes an extensive study on standard supervisory assessments and analyzes the link between standard assessments and financial performance measures. They conclude that while there is no perfect supervisory approach, the lack of certain key features in a supervisory approach is likely to lead to macro-financial consequences.

From a theoretical perspective, the relationship between regulation and supervision and bank performance is not straightforward. The greater part of earlier policy literature on financial 
regulation has been inspired by the broader debate on the role of government in the economy. The two best-known opposing camps in this field are the public interest and the private interest defenders, who both, nonetheless, agree on the assumption of market failure (Barth et al, 2006). For the public interest camp, governments regulate banks to ensure better functioning and thus more efficient banks, ultimately for the benefit of the economy and the society (Feldstein, 1972). According to the public interest view, which largely dominated thinking during the 20th century, regulators have sufficient information and enforcement powers to promote the public interest. In this setting, well-conceived regulation can exert a positive effect on firm behavior by fostering competition and encouraging effective governance in the sector. In contrast, according to the private interest view, efficiency may be distorted because firms are constrained as to where they channel resources. These complex interactions may have conflicting effects on the efficiency of the banking system.

The empirical literature investigating the impact of financial regulation has mainly focused on the impact on bank performance and risk taking, with mixed outcomes. A number of studies employ the World Bank surveys on bank regulations and supervision to construct measures of bank regulation and supervision. ${ }^{3}$ In general, these studies find that regulations that empower private sector monitoring have a positive impact on bank performance. One of the earlier studies is by Barth et al. (2004), who report that policies that promote accurate information disclosure and provide incentives for private sector' corporate control work best to promote bank development, performance and financial sector stability.

Using information from the abovementioned World Bank database, Agoraki et al, (2011) construct indices to proxy capital requirements, official supervisory power and restrictions on bank activities and find that these regulations reduce banking risk, but suggest that the overall effect depends on banks' market power. Klomp and DeHaan (2012) on the other hand, find that the impact of bank regulation and supervision on banking risk is not uniform, with the most significant effect on riskier banks.

A number of studies have focused on the relationship between regulation and supervision and bank efficiency (Fries and Taci 2005; Grigorian and Manole 2006; Pasiouras et al, 2009; Chortareas et al, 2012). Overall, their results corroborate the role of market discipline and of supervisory power in increasing both profit and cost efficiency, although the evidence on capital regulation remains mixed. A recent study by Barth et al, (2013) examine whether bank regulation, supervision and monitoring enhance or hinder bank efficiency and highlight potential trade-offs between bank safety and soundness and bank efficiency.

One key shortcoming of this literature is that it attempts to assess the quality of bank regulation and supervision by using proxies of supervisory authorities' attributes, such as independence and scope of powers. Survey information only reflects whether laws or regulations are on the books, but not to what extent they are implemented in practice. ${ }^{4}$ Only a handful of

\footnotetext{
${ }^{3}$ Barth et al., (2001, 2006, 2008, 2012)

${ }^{4}$ Cihak and Tieman (2008) compare the World Bank survey data and the BCP assessments and find that the correlation is low, therefore concluding that compliance in most countries is different from on-the-books regulation. Of course, assessing regulatory compliance is not an exact science and individual assessment might be influenced by
} 
papers use an alternative to the World Bank survey data and employ an index measuring the extent to which countries adhere to the Core Principles for Effective Bank Supervision as issued by the Basel Committee on Banking Supervision (BCPs). The Core Principles summarize best practice and have been endorsed by most countries in the world, effectively resulting in an almost universal standard for banking regulators (Demirgüç-Kunt et al, 2008). Since 1999, the IMF and the World Bank have conducted evaluations of member countries' compliance with these standards and therefore these assessments provide a unique source of information about the quality of supervision and regulation around the world.

The earlier studies using BCPs data (Sundararajan et al, 2001; Podpiera, 2004; Das et al, 2005) do not find evidence to support the hypothesis that better compliance leads to a sounder banking system. Demirgüç-Kunt et al (2008) rely on compliance with the BCP to investigate whether better banking supervision and regulation is associated with sounder banks. They proxy bank soundness with Moody's financial strength ratings and find that banks receive higher ratings in countries with higher compliance scores related to information provision. On the other hand, compliance with the other Core Principles does not affect bank ratings. More recently, Demirgüç-Kunt and Detragiache (2011) extend the set of countries used in the empirical analysis and find that BCP compliance is not robustly associated with bank soundness, proxied by a system-wide z-score.

Our study builds on this literature and evaluates how compliance with BCP affects bank performance for a large sample publicly listed banks drawn from a broad cross-section of countries. This is the first study to comprehensively analyze whether BCP compliance is associated with bank operating efficiency. While regulatory compliance might foster bank stability, it may also interfere with the efficient operation of banks. In addition, a higher regulatory burden may create incentives for banks to engage in riskier activities and regulatory arbitrage. This could affect negatively bank performance and ultimately affect financial stability. Thus, we believe our work improves upon existing studies by using a more comprehensive measure of bank performance. In addition, our data sample includes all IMF and World Bank assessments, from their initial ones in 1999 up to 2014. This enables us to include countries that have been assessed twice (in some cases even three times) therefore minimizing the bias potentially introduced by assessors' experience, personal views, cultural and regulatory differences and existing macroeconomic conditions.

\section{Data ANd Methodology}

\subsection{The Sample}

The dataset used in this study comprises bank-level data and country-level data; it is compiled from a number of sources: (a) the IMF and World Bank Basel Core Financial Sector Assessment Program (FSAP) database, which includes detailed assessment of a country's

many factors, including the assessors' experience and the existing regulatory framework (Demirgüç-Kunt and Detragiache, 2011). 
compliance with the Basel Core Principles for Effective Bank Supervision (BCP) during 19992010; (b) the Barth et al, (2004, 2006, 2008 and 2012) surveys on bank regulation, supervision, and monitoring; (c) the World Bank Economic Indicators database (WDI); and (d) the Bankscope database provided by Bureau van Dijk and Fitch Ratings.

Bank-level information comprises balance sheet and income statement data for all publicly quoted commercial banks and bank holding companies. We focus on publicly quoted banks, on the assumption that these institutions are subject to more stringent regulatory controls and need to comply with international regulations, such as capital regulation. This focus should also enhance cross-country comparability, not least because publicly quoted banks follow international accounting standards to report end-of-year accounting variables (Laeven and Levine, 2009). When constructing the dataset, we exclude banks with missing information on relevant accounting variables (total assets, loans, other earning assets, deposits, equity capital, interest and non-interest income, and interest and non-interest expenses). To prevent the possibility of outliers driving the results, we following a two-step procedure; first, we winsorize the input and output variables at the $1 \%$ level. ${ }^{5}$ In a second step, we apply data cloud methods to identify and remove outliers in terms of the input/output mix (see Section 3.4 for more detail on input and output specification). ${ }^{6}$

We then match the bank-level information with country-level information to investigate the link between regulatory compliance and bank performance, accounting for cross-country differences in macroeconomic and institutional factors. Our final cross-sectional sample includes 1,146 banks across 75 countries over the period 1999-2014 (Table A.1). ${ }^{7}$ Our sample includes countries with vastly different banking systems and economic conditions, with some countries only represented by a few listed banks, while others have a much higher sample share. Specifically, U.S. banks account for approximately 25 percent (296 banks) of the sample. To ensure that our findings are not overly influenced by U.S. banks, we examine results with and without them.

For the purpose of the analysis, we categorize the 75 countries in our sample both in terms of both economic development and geographic region, combining information from the International Monetary Fund (IMF) and the European Bank for Reconstruction and Development (EBRD). Countries are classified into four categories of economic development: (i) Major Advanced (countries in the G7 group); (ii) Advanced, (iii) Emerging and Developing; and (iv) Transitional. In addition, countries are also classified into 11 geographical regions (see Section 3.6 for more details)

Because the country-level regulatory data (data source (b)) are collected in four survey exercises (1999, 2003, 2007 and 2011), following Barth et al. (2013) we match the data for the regulatory variables as follows: the 1999 survey data are used for period 1999-2002; the 2003

\footnotetext{
${ }^{5}$ For robustness, this procedure was repeated at the 5\% and 10\% levels and the results are qualitatively similar.

${ }^{6}$ This method allows for the identification of "influential observations" in the application of Data Envelopment Analysis (see Wilson, 1995).

${ }^{7}$ The original BCP assessment exercise examines 158 countries, principalities, and monetary unions; but because of data availability and the incomplete overlap among the four databases, the dataset's global span is reduced to 75 countries.
} 
survey data are used for period 2003-2006, 2007 survey data are used for period 2007-2010, and the 2011 survey data used for the period 2011-2014.

As each bank in the sample is assessed at one point in time during the sample period, the data is cross-sectional.

\subsection{Empirical Set-Up and Definition of Variables}

Frontier methodologies for the analysis of firm performance have generated a large literature since the seminal work of Leibenstein (1966) introduced the concept of x-inefficiency as the gap between ideal efficiency and actual efficiency. Frontier approaches measure firm performance relative to 'best practice' in the industry. Such measures summarize performance in a single statistic that controls for differences among firms using a sophisticated multidimensional framework (Banker et al, 2010). The evaluation of efficiency is based on the assumption that the production frontier of the fully efficient organization is known. In practice, data is used to estimate this idealized frontier. Over the last half-century, estimations of this best practice frontier developed along two empirical paths: a parametric and a non-parametric one. In this study, we follow a non-parametric approach that uses linear programming methods to assign each observation to its own set of 'coefficients' from which inefficient behavior can be assessed. More specifically, we employ the most well known of these 'data-oriented' methods, Data Envelopment Analysis (DEA), first introduced by (Charnes et al, 1978) and later extended by (Banker et al, 1984). Our methodological approach represents an extension of the traditional DEA model.

Formally, DEA is a methodology directed to frontiers rather than central tendencies. It floats a piecewise linear surface to rest on top of the observations rather than fitting a regression plane through the 'middle' of the data using statistical methods (Cooper et al, 2011). DEA produces exact in-sample estimates of efficiency; that is a measure of the performance of an institution relative to the other institutions that are producing the same good or service. This method is non-stochastic; it assumes that all deviations from the frontier are the result of inefficiency. This represents a drawback of the approach, as statistical inference about estimates comparisons are precluded without further simulation techniques such as bootstrapping. To overcome this problem, we follow a double bootstrapping procedure, as proposed by Simar and Wilson (2007).

Another of the key issues that arises in the use of frontier methods for cross-country comparisons of bank efficiency is the existence of significant heterogeneity. Several studies have proposed alternative methodologies to overcome this problem. In this paper, we begin with the estimation of a common global frontier by means of Data Envelopment Analysis (DEA). In the next step, to account for cross-country heterogeneity we adopt a form of the two-stage approach with a double bootstrapping procedure (Simar and Wilson, 2007). In this two-stage approach, the first stage measures efficiency by a DEA estimator and the second stage uses truncated regression to infer how various (bank-specific and country-specific) factors influence the (biascorrected) estimated efficiency. The choice of this methodological approach is driven by the characteristics of our sample, which includes a large number of countries (and a relatively small number of banks per country) and therefore presents considerable challenges to accounting for 
differences in operating, regulatory, and macroeconomic conditions experienced by banks. ${ }^{8}$ Our study is the first cross-country study to apply the double bootstrapping two-stage procedure in a consistent manner. ${ }^{9}$

In more detail, our approach can be broken up into three steps. In the first step, we use a nonparametric input-oriented DEA model to measure bank efficiency. ${ }^{10}$ However, ignoring the complex and heterogeneous nature of the sample and simply benchmarking performance on the basis of a global common frontier would yield biased efficiency estimates. As a consequence, in the next stage, we apply the double bootstrapping procedure proposed by Simar and Wilson (2007) to explicitly account for the complex serial correlation in a two-stage DEA efficiency estimation. ${ }^{11}$ In the estimation of DEA technical efficiency scores, this procedure recognizes that certain bank-specific and environmental variables influence the estimate of the true unobserved efficiency score and is thus consistent with the second-stage truncated regression analysis (Glass et al, 2010).

In a second step, the results from a truncated regression of the initial DEA efficiency estimates on a set of environmental variables are used in a nonparametric bootstrap to generate biased corrected efficiency estimates. This step adjusts for the influence on the DEA efficiency estimations of the correlation between observable bank/country level factors and the inputs/outputs in a bank production process. Finally, in a third step, the bias-corrected DEA efficiency estimates from step two are used as the dependent variable in a further truncated regression on the same set of environmental variables, and a parametric bootstrap is used to provide more efficient estimates of the statistical relationships between the environmental variables and bank efficiency.

\subsection{Estimating Bank Efficiency}

We proceed to evaluate banks' operating efficiency as follows. Let us define a production set as

\footnotetext{
${ }^{8}$ An alternative methodology that is popular in cross-country studies is the meta-frontier approach (Battese et al., 2004), which allows for the estimation of technology gap ratios between individual country frontiers and the overall meta-frontier, which is derived as an envelopment of individual frontiers. For applications of the meta-frontier approach is banking, see, among others Bos and Schmeidel (2007) and Casu et al. (2013). Because our study is limited to publicly listed companies, it does not include a sufficiently large number of observations per country to allow the estimation of individual country frontiers as well as a meta-frontier.

${ }^{9}$ Some previous studies (Brissimis et al.. 2008; Delis and Papanikolaou 2009) have applied the bootstrapping procedure (more specifically, they have applied algorithm 1 from Simar and Wilson (2007) which improves inference but does not take into account the bias as detailed in equation (4)). Barth et al.. (2013) use the procedure as a robustness test without indication of the extent of its use.

${ }^{10} \mathrm{As}$ a further robustness test, the original (raw) DEA estimates were used to create a subsample that excluded banks on the frontier $(=1)$. This subsample was then used to re-estimate efficiency. The correlation between efficiency results of this reduced subsample was found to be statistically similar (a Pearson and Spearman rank correlation coefficient were significant at the 1 percent level) to the original estimates, a good indication that outliers haven't affected the results to a large extent (Casu and Molyneux, 2003).

${ }^{11}$ Specifically we employ Algorithm 2 in Simar and Wilson (2007), which corrects for (i) bias in DEA estimates, (ii) serial dependence among DEA estimates (of unknown structure), and (iii) the DEA-related artefact of placing probability mass at 1 for some observations.
} 


$$
\mathbb{P}=\{(x, y): x \text { can produce } y\}
$$

where $x \in \mathbb{R}_{+}^{p}$ denotes a vector of $p$ inputs and $y \in \mathbb{R}_{+}^{q}$ denotes a vector of $q$ outputs. The technology or production frontier is defined as

$$
\mathbb{P}^{T}=\{(x, y) \mid(x, y) \in \mathbb{P},(\theta x, y) \notin \mathbb{P} \forall 0<\theta<1\}
$$

which is then used to measure the $i^{\text {th }}$ banks' input technical efficiency, defined as

$$
\delta_{\text {input }}\left(x_{i}, y_{i}\right) \equiv \inf \left\{\theta>0 \mid\left(\theta x_{i}, y_{i}\right) \in \mathbb{P}^{T}\right\}
$$

the proportion by which input quantities can be reduced without reducing output quantities (Coelli et al, 2005). ${ }^{12}$

When a large cross-country sample is used to build a best-practice frontier, inefficiency for bank $i$ in country $j$ is measured in terms of distance from this global common frontier. This implies that any cross-country differences in the initial DEA efficiency scores are entirely attributed to bank-level managerial decisions regarding the scale and mix of inputs. If this assumption is not correct, it will result in biased efficiency estimates. In the next two steps, unlike most cross-country bank efficiency studies, we apply a double bootstrapping procedure (Simar and Wilson, 2007) to account explicitly for the complex serial correlation in a two-stage DEA efficiency study. This procedure will adjust for the bias in the first stage DEA estimates of bank efficiency. We will then use these bias-corrected efficiency scores to improve statistical efficiency in the second-stage truncated regression estimates.

Mathematically this bias can be described as follows:

$$
\delta_{i}=\widehat{\delta_{l}}-\operatorname{BIAS}\left(\widehat{\delta}_{\imath}\right)-\mu_{i}
$$

where $\delta_{i}$ is the true (unobservable) efficiency score for $i^{\text {th }}$ bank, $\widehat{\delta_{l}}$ is the nonparametric DEA estimate of $\delta_{i}, \operatorname{BIAS}\left(\widehat{\delta}_{l}\right)$ is the bias of the nonparametric estimate which is strictly negative in finite samples, and $\mu_{i}$ is the error in the nonparametric estimate, which will disappear asymptotically. ${ }^{13}$ As can be seen from (4) the true unobserved efficiency scores are generally downward biased, and nonparametric efficiency estimates that ignore this bias will provide a more favorable estimate of efficiency. In the context of our study, the bank would appear to be performing better, in terms of the efficient allocation of its resources, than is actually the case. Our estimation will implicitly account for this bias.

\footnotetext{
${ }^{12}$ We report efficiency scores based on a variable returns to scale (VRS) assumptions.

${ }^{13}$ This is equation 16 in Simar and Wilson (2007).
} 


\subsection{Definition of Inputs and Outputs}

The inputs and outputs used to estimate efficiency are defined based on an extension of the intermediation approach (Sealey and Lindley, 1977), which does not penalize nontraditional banking activity and takes into account a bank's ability to manage risk. We estimate a model that has three inputs and three outputs.

The inputs are: (i) customer deposits and short-term funding; (ii) total costs (defined as the sum of interest expenses and noninterest expenses), and (iii) equity capital to adequately account for the impact of risk (Berger, 2007). Hughes and Mester (2010) argue that the inappropriate treatment of equity capital can bias bank efficiency estimates because banks can use either capital or deposits to fund loans, and this choice has a direct effect on funding costs. ${ }^{14}$ As equity capital has a minimum level due to capital adequacy regulation, it should be treated as a quasi-fixed input; a variable whose control is not at the complete discretion of the management. ${ }^{15}$

The three outputs are: (i) loans; (ii) other earning assets; and (iii) noninterest income as a proxy for off-balance-sheet activities. ${ }^{16}$ We include the latter output to ensure that we do not penalize banks that have a substantial share of nontraditional activities (Barth et al, 2013)

\subsection{Measuring Bank Compliance}

The principal variable of interest, BCP compliance, is derived from the IMF and World Bank Basel Core Financial Sector Assessment Program (FSAP) database. ${ }^{17}$ Our study extends the work of Demirgüç-Kunt and Detragiache (2011) by using assessment data covering 1999-2010, which includes a U.S. banking sector assessment. ${ }^{18}$ The Basel Core FSAP is an exhaustive global exercise, capturing the compliance features of banking industries in both developed and developing economies. The $25 \mathrm{BCP}$ core principles are considered by regulators and by international organizations to be the best practice to date of compliance with banking regulation and supervision. These principles were issued in 1997 by the Basel Committee of Banking Supervision, and have been adopted by most countries in the world. Since 1999, the IMF and the World Bank have conducted regular assessments to gauge countries' compliance with these principles, mainly within their joint FSAP. The $25 \mathrm{BCP}$ core principles are organized into seven chapters which measure: Preconditions for effective banking supervision (Chapter 1); Licensing

\footnotetext{
${ }^{14}$ Hughes and Mester (2010) argue that most bank efficiency studies make use of financial statement data and define costs based on an accounting cash-flow concept rather than economic principles, the former using interest paid on debt (deposits) and not the cost of equity. This would mean that if a bank chooses to substitute some of its equity capital for debt its cash-flow costs will rise, making the less-capitalized bank appear more costly than the wellcapitalized bank.

${ }^{15}$ In an input-oriented model we would thus treat equity as a negative output, (Bogeoft and Otto, 2011).

${ }^{16}$ Although other studies have used the value of off-balance-sheet items, this variable has a significant number of missing values in our sample; thus, we rely on noninterest income as an appropriate proxy.

${ }^{17}$ For detailed information on the assessments of the Basel Core Principles, we refer the reader to their founding documents (Basel Committee on Banking Supervision 1997, 1999, 2006, 2011a, 2011b, 2012).

${ }^{18}$ Demirgüç-Kunt and Detragiache (2011) use BCP compliance data covering the period 1999-2007.
} 
and structure (Chapter 2); Prudential regulations and requirements (Chapter 3); Methods of ongoing supervision (Chapter 4); Information requirements (Chapter 5); Formal powers of supervisors (Chapter 6): and Cross-border banking (Chapter 7). See Table A.3 for more details on the variables constructed from these chapters).

Following Demirgüç-Kunt and Detragiache (2011), the level of bank compliance is assessed using an aggregate $\mathrm{BCP}$ compliance score and a disaggregated approach, to distinguishing among various dimensions of regulation and supervision. The variable "BCP compliance" specifies a measure of compliance for each country in our sample at one point in time. Banklevel and country-level information are matched with the year of assessment to produce a crosssectional sample. More specifically, to assess the compliance rate with each of the 25 principles, a four-point scale is used: (i) noncompliant; (ii) materially noncompliant; (iii) largely compliant, and (iv) compliant. Numerical values are assigned to each of the grades (from 0 for noncompliant to 3 for compliant). An overall index of compliance is computed based on the sum of the seven regulatory dimensions (BCP score). Seven indexes of compliance are then calculated based on the individual dimensions of regulation. All indices are normalized to take values in the interval $[0,1]$. This normalization also has the intuitively appealing property of a percentage interpretation on initial analysis.

\subsection{Environmental Variables}

Bank efficiency is normally expressed as a function of both internal and external contextual variables. Internal factors are usually related to bank management and are defined from a bank's financial statements and thus specific to its individual character. External factors describe the regulatory, macroeconomic, and financial development conditions that are likely to affect a bank's performance. The contextual variables used in this study are chosen to best fit the primary purpose of the analysis and include both bank-specific and country-specific variables.

The bank-specific variables include log of total assets (logta), loans to assets ratio (lta), book value equity to assets (eqta) and return on equity (roe). Bank size, lending behaviour, capitalization, and risk profile are considered key determinants of bank performance.

It has long been established in applied bank efficiency studies that bank size (logta) can significantly affect bank performance. Banks enjoy economies of scale as they grow larger. One of the reasons put forward in the literature is that larger banks can better diversify risk (particularly credit and liquidity risk), which should reduce the relative costs of risk management. This in turn should allow banks to conserve equity capital, reserves, and liquid assets. Further, the spread of overhead costs (especially those associated with information technology) can also bring about larger efficiencies of scale in banking production (Hughes and Mester, 2013). Although large banks can experience scale diseconomies and there might be costs associated with diversification, we expect an overall positive relationship between size and efficiency.

A bank's production process is underpinned by its ability to improve information asymmetries between borrowers and lenders. This implies that a measure of relative lending behavior such as loans to assets (lta) can be an important determinant of bank performance. Furthermore, as banks make choices about their capital structure and the amount of risk to 
assume, capitalization decisions have a direct impact on performance. We model this potential impact by including equity to assets (eqta). We expect higher levels of capital to be related to a reduction in a bank overall risk, and posit a positive relationship between the equity to assets ratio and bank performance. Finally, we also control for performance differences resulting from a manager's ability to optimize the risk-return tradeoff, by including a bank's return on equity (roe). Although no consistent picture emerges in the literature as to the relationship between risk and bank efficiency, a bank risk-taking profile is an important determinant of performance.

Moving to the external country-specific characteristics, these are a vector of the macroeconomic conditions and financial conditions in the banking industry of each country in the sample. The business and economic cycle fluctuations are modeled using annual growth in GDP (gdpg) and annual rate of inflation (inf) measured as the percentage change in the consumer price index. Favorable economic conditions will stimulate an improvement in the supply and demand for banking services, and will consequently have a positive effect on bank efficiency (Lozano-Vivas and Pasiouras, 2010). Furthermore, high inflation can affect bank performance in a number of ways: it might encourage banks to compete through excessive branch networks, thus affecting cost (Kasman and Yildirim, 2006), or it might have a beneficial effect on bank margins (Demirgüç-Kunt et al, 2004).

The level of financial intermediation is controlled by including the ratio of private sector banks' claims to GDP (PrCrGDP) as in (Barth et al, 2004). A higher ratio indicates increased loan activity, which is likely to improve bank efficiency. Higher efficiency resulting from high intermediation activity may be the effect of a bank's risk preferences; recall that our model takes this into consideration by including equity capital as both a quasi-fixed input and in ratio form (eqta) as an environmental variable.

Lastly, we control for bank sector concentration using the ratio of the assets held by the three largest banks as a proportion of all bank assets of the country (conc). Higher concentration is thought to have a negative impact on bank efficiency because market power allows managers to relax their efforts to improve performance (Berger and Hannan, 1998). ${ }^{19}$

The primary purpose of our study is to investigate whether BCP compliance plays a role in bank performance; therefore, it is vital to appropriately model the regulatory conditions within which each bank operates. We include six key features of banking regulation, which were first defined in Barth et al, (2004, 2006). RESTR is a measure of the level of restriction placed on a bank's activity. Barth et al, (2004) argue that allowing banks to be involved in a range of activities may encourage the rise of larger, more complex entities that are more difficult to regulate. Reduced competition and efficiency may result, because banks may systemically fail to manage their diverse set of financial activities beyond the traditional model, lowering profitability (Barth et al, 2003).

COMP measures the level of regulation in place that would reduce competition (this includes entry requirements, limitations of foreign bank entry/ownership, and the fraction of new

\footnotetext{
${ }^{19}$ It has also been argued that higher concentration could be the result of efficiency in the production process (Lozano-Vivas and Pasiouras, 2010).
} 
applications for banking licenses that are denied). As mentioned above, limited competition is likely to induce appropriating management behavior that may have a detrimental effect on bank efficiency. CAPRQ measures capital risk management restrictions. Pasiouras et al, (2009) argue that capital requirements can affect bank efficiency and productivity in three ways. First, binding regulatory capital requirements reduce aggregate lending and affect loan quality, which in turn will affect efficiency. Second, stricter capital requirements influence a bank's asset portfolio mix, resulting in different portfolio returns; this will affect input-oriented bank efficiency, because these returns will require the management of different resources. Finally, as mentioned earlier, differing capital standards will influence a bank's decisions on the mix of deposits and equity, which entail different costs.

PRMON is a variable measuring the degree of private sector monitoring. This is a proxy for the third pillar of Basel II and can be related to the private monitoring hypothesis, which argues that supervisory power can incorporate business corruption and/or political motivation which, if increased, would affect bank lending integrity and compromise efficient credit allocation. ${ }^{20}$ Many economists support a greater reliance on private sector monitoring to promote better-functioning banks, although the quality of private monitoring largely depends on the quality of information disclosure. Although we expect the effect to be country-specific, we expect a positive link between the degree of private market monitoring and bank efficiency.

DEPSEC is a measure of the amount of security in place for depositors, in terms of deposit insurance schemes. Research suggests that increased levels of deposit insurance will exacerbate moral hazard issues and reduce the incentives for private monitoring. In terms of the effect on bank efficiency, higher levels of security for depositors would reduce banks' incentives to efficiently allocate resources to the most productive opportunities, thereby resulting in a negative effect on efficiency.

CORPGOV is a measure of the level of effective corporate governance; it is derived from the External Governance Index. Better external governance is expected to enhance the private monitoring and disciplining of banks and thus boost banking efficiency.

Finally we control for differences in economic development of the countries in our sample. Countries are classified into four categories (Major Advanced, Advanced, Emerging and Developing, and Transitional) by development status. In addition, to capture regional differences we also classify the countries 11 regions: Centrally planned Asia and China (CPA); Central and Eastern Europe (EEU); Latin America and the Caribbean (LAM); Middle East and North Africa (MEA); Newly Independent States of Former Soviet Union (FSU); North America (NAM); Other Pacific Asia (PAS); Pacific OECD (PAO); South Asia (SAS); Sub-Saharan Africa (AFR) and Western Europe (WEU).

\footnotetext{
${ }^{20}$ The antithesis is the official supervision hypothesis, which suggests that supervision can prevent systemic failures by direct oversight, regulation, and disciplinary action against banks.
} 


\subsection{Methodology}

The relationship between bank efficiency and regulatory compliance is evaluated using the following baseline specification:

$$
E F F_{i, j}=\beta_{0}+\beta_{1} \text { BCPIndex }_{j}+\beta_{2} \mathbf{B}_{i, j}+\beta_{3} \mathbf{M F}_{j}+\beta_{4} \mathbf{R}_{j}+\beta_{5} \mathbf{I}_{j}+\epsilon_{i, j}
$$

where $i$ indexes bank $i, j$ indexes country $\mathrm{j}, E F F_{i, j}{ }^{21}$ is the efficiency score of bank $i$ in country $j$, estimated by means of Data Envelopment Analysis and bias-corrected, as discussed in Section 3.3. BCPIndex $j$ is the overall compliance index for country $j$, as discussed in Section 3.5. The remaining environmental variables are included to capture observable cross-country and bankcharacteristic differences. These have been discussed in Section 3.6; Table A.3 presents the details of how variables were constructed.

More specifically, $\mathbf{R}_{j}$ is a vector of bank regulatory condition indicators (described in Barth et al, (2006) for country $j ; \mathbf{M F}_{j}$ is a vector of macroeconomic and financial condition variables for country i; $\mathbf{B}_{i, j}$ is a vector of bank-specific characteristics for each bank $i$ in country $j$, and $\mathbf{I}_{j}$ is a vector of dummy variables controlling for regional or economic development differences. The error terms $\epsilon_{i, j}$ and $\omega_{i, j}$ are assumed to be random noise elements of the dependent variable $E F F_{i, j}$.

We estimate the model using a truncated regression in the double bootstrap procedure, as detailed in Section 3.3.

In a second step, we decompose our main variable of interest, BCP, into the seven component chapters using the following disaggregated model: $:^{22}$

$$
E F F_{i, j}=\beta_{0}+\beta_{1} \mathbf{B C P c h}_{j}+\beta_{2} \mathbf{B}_{i, j}+\beta_{3} \mathbf{M F}_{j}+\beta_{4} \mathbf{R}_{j}+\beta_{5} \mathbf{I}_{j}+\omega_{i, j}
$$

where $\mathrm{BCPch}_{j}$ is an index of compliance, calculated based on the individual dimensions of regulation: $\mathrm{BCPch}_{1}$ is Preconditions for Effective Banking Supervision; $\mathrm{BCPch}_{2}$ is Licensing and Structure; $\mathrm{BCPch}_{3}$ is Prudential Regulations and Requirements; $\mathrm{BCPch}_{4}$ is Methods of OnGoing Supervision; $\mathrm{BCPch}_{5}$ is Information Requirements; $\mathrm{BCPch}_{6}$ is Formal Powers of Supervisors, and $\mathrm{BCPch}_{7}$ is Cross-Border Banking. The remaining variables are defined as in equation (4).

\footnotetext{
${ }^{21}$ Depending on the steps of our analysis this variable will differ. In the second step of our approach this would be the original DEA score estimated in the first step. In the third step of our approach this would be the bias-corrected efficiency estimate from the second step.

${ }^{22}$ Given the high correlations between the BCP chapters, we used Principal Component Analysis (PCA) and the first principal component of each chapter was also used to assess whether bank input efficiency was harmed by sub chapter compliance. The empirical results were broadly similar to those reported in the main findings in Table $3 \mathrm{a}$ and $3 \mathrm{~b}$.
} 


\subsection{Summary Statistics}

Table 1a presents summary statistics of the full sample. Panel 1 describes the mean and standard deviation of each variable, while panel 2 provides an exposition of the median values categorized by economic development. Table $1 \mathrm{~b}$ presents the correlation matrix of the $\mathrm{BCP}$ chapters. A few salient features emerge.

[Table 1a: Descriptive Statistics]

[Table 1b: Correlation Matrix]

Bank-level variables in panel 1 illustrate a host of differences between the 75 nations in our cross-country survey, indicative of variations in banking industry sophistication. The median values suggest that the sample is positively skewed, with a small number of large banks. Furthermore, there is a high degree of full-sample heterogeneity, with values varying widely about their means according to standard deviation figures.

From panel 1 the full-sample mean of the overall BCP compliance index (BCPscore) is 0.27, a much lower value than in the Demirgüç-Kunt and Detragiache (2011) study. This difference is likely owing to the inclusion of the U.S. banking sector, which dominates the sample and performed poorly in their $2010 \mathrm{BCP}$ compliance assessment.

From panel 2 a number of interesting sample features emerge. First, overall compliance with the $\mathrm{BCP}$ appears to be higher in emerging and developing countries (47 percent), suggesting that these countries adhere more closely to $\mathrm{BCP}$ because their banking industries are nascent. A closer look at the regulatory control variables of emerging market and developing countries also suggests that these banking industries have many more restrictions placed on their activities $($ RESTR $=0.61)$, lack competition $(\mathrm{COMP}=0.64)$, and have negligible security in place for depositors (DEPSEC $=0.02$ ). All these characteristics would suggest a greater sensitivity to $\mathrm{BCP}$ compliance of banks in developing countries.

\section{Empirical Results}

This section presents the results of our empirical analysis. First we present the biascorrected efficiency estimates. We then present the results of the truncated regression analysis to infer how various (bank-specific and country-specific) factors influence the (bias-corrected) estimated efficiency.

\subsection{Efficiency Estimations}

We begin our empirical investigation with the estimation of (bias-corrected) efficiency scores. Table 2 presents summary statistics for the bias-corrected DEA estimates. These include 
the coefficient of variation ( $\mathrm{CV}$, the standard deviation scaled by the mean). ${ }^{23}$ This is a scale-free measure of dispersion that represents a comparative measure of efficiency volatility, with lower values indicative of more stable bank performance.

The results are presented in three panels, one for each of the groupings mentioned above. In panels 1 and 2 estimates are disaggregated by level of economic development, while in panel 3 the disaggregation is by geographical region.

Firstly, the overall mean bias-corrected input technical efficiency is 0.479 (the equivalent mean for the Non-U.S. bank sample and the emerging market and developing countries bank sample are 0.542 and 0.649 respectively). This mean value implies that a typical bank could improve its input efficiency by 52 percent; or, if the average bank were producing on the frontier rather than at its current location, only 48 percent of inputs being used would be required to produce the output set.

This global average is lower than in recent studies (Lozano-Vivas and Pasiouras 2010; Pasiouras 2008) that used DEA methods and similar samples. This difference is perhaps attributed to our explicit treatment of sample heterogeneity in the efficiency estimates.

As discussed above, nonparametric efficiency estimates using a heterogeneous global sample are inherently biased and will provide a more favorable picture of bank efficiency if this bias is ignored. A comparison of the overall mean raw efficiency ${ }^{24}(0.596)$ and its bias-corrected counterpart (0.479) suggests that, on average, this estimated bias is 0.11 . The comparative estimate of average bias in the non-U.S. and emerging market and developing country bank samples is 0.068 and 0.14 respectively. ${ }^{25}$ The bias-corrected efficiency estimates thus reveal that the performance of banks is generally more inefficient than the raw, uncorrected DEA estimates suggest.

\section{[Table 2: Bank efficiency estimates]}

Second, there are some trends evident when moving from advanced to less advanced economies. In panel 1, mean efficiency scores exhibit little difference across major advanced and advanced country banks, while banks located in emerging market, developing, and transition countries are, on average, less efficient. Panel 2 results for the non-U.S. sample provide a much clearer picture of this trend. The most efficient banks are located in the major advanced countries (mean=0.619) while the least efficient banks are located in the emerging market and developing countries $($ mean $=0.498)$.

\footnotetext{
${ }^{23}$ The coefficient of variation is also known as the relative standard error; the standard error of an estimate (in this instance the mean) divided by the estimate itself.

${ }^{24}$ The summary statistics of these original (raw) DEA estimates are presented in Table A.2 of the appendix.

${ }^{25}$ To provide a complete picture of the bias, these averages should be assessed in conjunction with their standard deviations. The standard deviation of the bias estimates for the full, non-U.S., and emerging market and developing country bank samples are $0.09,0.11$, and 0.22 respectively. The latter suggests the average bias in the emerging and developing has much more variability around its mean value. This increased variability is likely the result of much greater heterogeneity across banks in this subsample.
} 
Third, there appears to be an increase in the dispersion of bank efficiency estimates as we move from the most developed to the least developed countries. Panels 1 and 2 show some differences in the coefficient of variation across developmental levels, with major advanced country banks exhibiting the most stability in efficiency estimates (lower CV figure) while emerging market and developing country banks experience the most volatility in efficiency estimates (higher CV figure). This trend is most pronounced in the full sample, where the coefficient of variation of the emerging and developing country banks (0.917) is double the corresponding figure for major advanced country banks $(0.462)$.

The latter findings suggest that bank efficiency in emerging markets and developing countries is much more volatile. This increased volatility would suggest the necessity for tighter compliance with a set of effective banking supervision principles, and indicates the need for a more detailed analysis of these banks. Results from this analysis are summarized in panel 3: they suggest that a typical emerging market and developing country bank has a bias-corrected efficiency of 0.649 when benchmarked against best-practice peers of this subsample. ${ }^{26}$ This suggests that, on average, a bank producing on this emerging market and developing country bank frontier, instead of at its current location, would only need 65 percent of its inputs to produce the same amount of outputs. Overall there is little discernible difference across regions for banks located in emerging market and developing countries. ${ }^{27}$

\subsection{Truncated Regression Results}

The main aim of this study is to provide consistent estimation of the relationship between bank efficiency and BCP compliance, given the heterogeneous nature of the sample. Using the approach described in Section 3.7, we adopt two model specifications to provide a commentary on whether overall BCP compliance or compliance with any of its component chapters influence bank efficiency. Following Simar and Wilson (2007), we use a truncated regression model to investigate how producer-specific and country-level variables influence bank efficiency, with parameters being estimated by maximum likelihood. The authors' Algorithm 2 provides a consistent method to obtain the bootstrapped confidence intervals for these estimates. Specifically, the confidence intervals are constructed via the second part of the Simar and Wilson (2007) Algorithm 2 double bootstrapping procedure, using 30,000 replications. Table 3a presents parameter estimates for the full sample; Table $3 \mathrm{~b}$ provides parameter estimates for the sample

\footnotetext{
${ }^{26}$ This is the average distance of a typical bank from a global frontier built using a sample of only the emerging market and developing country banks.

${ }^{27}$ When regional comparisons are considered, no obvious trends emerge. Banks located in CPA countries 14 Chinese banks and 2 Vietnamese banks) are, on average, more efficient than those in other regions, with a mean bias-corrected technical efficiency of 0.75 . Furthermore, these banks experience more stability in their efficiency levels, with a lower coefficient of variation. At the other extreme, banks located in WEU countries (this category includes 10 Turkish banks) are, on average, the least efficient in all the regions, with a mean bias-corrected efficiency of 0.514 .
} 
excluding the U.S. banks, and Table 3c provides parameter estimates for the emerging and developing banks sample. ${ }^{28}$

\subsubsection{Effects of BCP compliance}

None of the regression results provide robust statistical evidence to suggest that overall BCP compliance or compliance with any of the individual chapters has a positive influence on bias-corrected bank efficiency. This adds further support to the argument that BCP compliance has no impact on the operational performance of individual banks, and may also reflect the inability of assessors to provide a consistent cross-country evaluation of effective banking regulation (Demirgüç-Kunt and Detragiache, 2011).

[Tables 3a \& 3b \& 3c: Truncated regressions]

\subsubsection{Effects of bank characteristics}

From Tables 3a-3c, it is clear that bank-specific variables play an important role in explaining the variability of bias-corrected bank input efficiency. Typically, larger, more actively lending banks (that is, banks with higher loan-to-asset ratios) are more efficient; this finding persists across the two subsamples.

\subsubsection{Effects of economic and financial conditions}

Across the groupings analyzed, no consistent relationships between bias-corrected input bank efficiency and economic/financial conditions emerge. The full sample assessment suggests that banks in countries with higher relative economic growth (illustrated by GDP growth) are typically more efficient. Moreover, higher levels of financial intermediation (illustrated by the ratio of private sector banks' claims to GDP - PrCrGDP) are positively associated with bank efficiency. These finding are consistent with previous studies (Lozano-Vivas and Pasiouras 2010; Pasiouras 2008) and suggest that favorable macroeconomic conditions will positively affect the supply and demand of banking services, improving bank efficiency.

The results provide some evidence to suggest that concentration in the banking industry has a detrimental effect on bank efficiency, as indicated by the negative association between bank concentration (CONC) and bias-corrected bank input efficiency, from model 1 results using the regional dummies.

\footnotetext{
${ }^{28}$ Given the high correlations between the BCP chapters; the first principal component of each chapter was also used to assess whether bank input efficiency was impacted by sub chapter compliance. The empirical results were broadly similar to those reported in the main findings in Table $3 \mathrm{a}-3 \mathrm{c}$.
} 


\subsubsection{Regulatory effects}

Similarly, there is little evidence of pattern when regulatory effects across the three groupings are considered. The full sample results provide some evidence to suggest that regulation which enhances private monitoring (PRMON) also increases bank efficiency, while regulation which stifles competition negatively affects bank efficiency. These findings add support to the private monitoring hypothesis; regulation that requires a bank to provide accurate and timely information to the public allows private agents to overcome information and transaction costs, enabling them to monitor banks more effectively. The latter finding is consistent with the recent finding that tighter restrictions on bank activities have a negative effect on bank efficiency (Barth et al, 2013).

Furthermore, there is some evidence to suggest that corporate governance has a positive influence on bank efficiency, while increased depositor protection and restrictions on activity have a negative impact.

\subsection{Regulatory Compliance in Emerging Markets}

Because of the significant differences between emerging markets and advanced economies, in this part of the analysis we focus on a sample of emerging market and developing economies. Differences in the level of institutional development, law and order, contract enforcement, and corruption, for example, may affect both the level of compliance and the efficiency of banking institutions. We therefore examine whether the impact of regulatory compliance on bank efficiency is conditional upon the level of development. A higher level of compliance would provide a secure environment for stable industry growth, and thus improve banking efficiency; however, regulatory compliance with international standards is costly and could negatively affect bank resource allocation.

To this end, we re-estimate the (bias-corrected) efficiency scores on our subsample of banks from emerging market and developing economies, and then proceed with the two-stage analysis. The results are reported in Table 3c. Although the results on the aggregate BCP index do not support the hypothesis of an association between regulatory compliance and bank efficiency, when we explore the relationship between efficiency and compliance with the different chapters or group of principles, we find some evidence of a negative relation. In particular, for banks in emerging countries, compliance with Chapter 4 (Methods of Ongoing Supervision) has a negative and significant impact on the bias-corrected efficiency measures. Specifically, this chapter relates to the effectiveness of the existing supervisory framework and ability of supervisors to carry out their duties. Against a background of (potentially) increased supervisory scrutiny required to meet international standards, banks are likely to face more substantive compliance costs, such as investments in accounting systems, risk management systems, equipment, and training. This in turn can distort their business objectives, lowering investment and decreasing lending, and resulting in lower efficiency.

On the other hand, the extent to which supervisors apply international global standards is positively associated with bank input efficiency (Chapter 7). This latter result may indicate that 
in emerging markets, adherence to international standards of best practice has a positive effect on bank performance.

\subsection{Sensitivity Analysis}

For the purpose of robustness we re-estimate the models using the Papke and Wooldridge (1996) fractional logit regression approach, as described in McDonald (2009). He argues that DEA efficiency is the outcome of a fractional logit process (taking values between zero and one) rather than a latent variable from a truncated process, as described by Simar and Wilson (2007). Using the raw uncorrected DEA estimates, the last four columns of Tables 3a-3c report the parameters estimated using quasi-maximum likelihood methods. Overall, the results seem to corroborate our key findings. Specifically, we continue to find no evidence of any beneficial relationship between bank efficiency and compliance with the BCPs.

\section{CONCLUSions}

This paper contributes to the ongoing debate on the impact of regulation and supervision on bank performance. Using World Bank Basel Core Principles for Effective Bank Supervision (BCP) assessments conducted from 1999 to 2014, we evaluate how compliance with BCP affects bank performance for a sample of 1,146 publicly listed banks drawn from a broad cross-section of 75 countries.

Our results indicate that overall BCP compliance, or indeed compliance with any of its individual chapters, has no association with bank efficiency. This result holds after controlling for bank-specific characteristics, the macroeconomic environment, institutional quality, and the existing regulatory framework, and adds further support to the argument that although compliance has little effect on bank efficiency, increasing regulatory constraints may prevent banks from efficiently allocating resources. When only banks in emerging market and developing countries are considered, we find some evidence of a negative relation with specific chapters that relate to the effectiveness of the existing supervisory framework and the ability of supervisors to carry out their duties. However, these results need to be treated with caution, because they may also reflect the inability of assessors to provide a consistent cross-country evaluation of effective banking regulation.

One limitation of this type of analysis is that compliance with the Basel Core Principles for Effective Bank Supervision (BCP) is measured at a particular point in time and does not allow for taking into account the evolution of each country's banking system in compliance with international regulatory standards. However, a small number of countries in the sample have been surveyed twice. By focusing on these countries, it would be possible to assess the impact of the changes in compliance scores, both for those countries whose bank performance has moved closer to international standards and for those countries which have underperformed.

As regulators refine and improve their approach and methodologies in response to the financial crisis, our result highlight the need to balance the objective of financial stability with an increasing number of rules that can potentially impact unfavorably on the efficiency of banks intermediation function. Our results show that, conditional on being a good bank, regulatory 
compliance per se has no association with bank performance and therefore an excessive confidence in rule-based regulation might hamper monitoring efforts and a deeper understanding of banks' risk taking. 


\section{TABLES IN BODY OF TEXT}

Table 1a: Descriptive Statistics

\begin{tabular}{|c|c|c|c|c|c|c|c|}
\hline \multicolumn{4}{|c|}{ Panel 1: Full sample summary statistics } & \multicolumn{4}{|c|}{$\begin{array}{c}\text { Panel 2: Median values by economic } \\
\text { development }\end{array}$} \\
\hline & Mean & Median & SD & Advanced & $\begin{array}{c}\text { Emerging } \\
\text { and } \\
\text { Developing }\end{array}$ & $\begin{array}{c}\text { Major } \\
\text { Advanced }\end{array}$ & Transition \\
\hline \multicolumn{8}{|l|}{ Bank level variables } \\
\hline \multicolumn{8}{|l|}{ Inputs (Mil \$) } \\
\hline Deposits and short term funding & $20,462.55$ & $3,961.49$ & $37,319.42$ & $34,311.71$ & $3,079.48$ & $2,369.86$ & 261.11 \\
\hline Total costs & 653.55 & 214.2 & $1,112.16$ & 627 & 191.42 & 121.71 & 28.35 \\
\hline Equity & $1,977.82$ & 404.79 & $3,691.60$ & $2,487.42$ & 291.33 & 241.7 & 41.24 \\
\hline \multicolumn{8}{|l|}{ Outputs (Mil \$) } \\
\hline Loans & $15,847.40$ & $2,712.63$ & $29,947.64$ & $27,006.05$ & $1,738.83$ & $1,891.88$ & 195.66 \\
\hline Other Earning Assets & $9,012.30$ & $1,469.77$ & $17,866.55$ & $13,414.36$ & $1,352.53$ & 737.44 & 74.58 \\
\hline Non-Interest Income & 260.74 & 45.1 & 516.89 & 236.01 & 46.53 & 24.41 & 9.7 \\
\hline \multicolumn{8}{|l|}{ Bank Characteristics } \\
\hline Total Assets (Mil \$) & $28,567.79$ & $5,018.05$ & $55,800.59$ & $43,343.16$ & $3,774.13$ & $3,060.73$ & 330.78 \\
\hline Loan to Assets & 0.58 & 0.61 & 0.15 & 0.61 & 0.56 & 0.65 & 0.57 \\
\hline Equity to Assets & 0.1 & 0.08 & 0.07 & 0.06 & 0.09 & 0.09 & 0.12 \\
\hline Return on Equity & 0.05 & 0.1 & 0.5 & 0.09 & 0.18 & 0.05 & 0.11 \\
\hline \multicolumn{8}{|c|}{ Country level variables } \\
\hline \multicolumn{8}{|l|}{ Regulatory variables* } \\
\hline RESTR & 0.56 & 0.61 & 0.14 & 0.47 & 0.61 & 0.61 & 0.44 \\
\hline COMP & 0.49 & 0.5 & 0.21 & 0.33 & 0.64 & 0.5 & 0.83 \\
\hline CAPRQ & 0.55 & 0.62 & 0.2 & 0.61 & 0.5 & 0.62 & 0.62 \\
\hline PRMON & 0.67 & 0.71 & 0.15 & 0.71 & 0.6 & 0.8 & 0.5 \\
\hline DEPSEC & 0.27 & 0.25 & 0.2 & 0.44 & 0.02 & 0.17 & 0.42 \\
\hline CORPGOV & 0.68 & 0.69 & 0.16 & 0.77 & 0.72 & 0.69 & 0.46 \\
\hline \multicolumn{8}{|l|}{$B C P$ variables* } \\
\hline BCPscore & 0.27 & 0.25 & 0.21 & 0.31 & 0.47 & 0.04 & 0.31 \\
\hline BCPch1 & 0.34 & 0.29 & 0.28 & 0.43 & 0.59 & 0 & 0.47 \\
\hline BCPch2 & 0.2 & 0.2 & 0.21 & 0.2 & 0.3 & 0 & 0.3 \\
\hline BCPch3 & 0.31 & 0.24 & 0.17 & 0.24 & 0.38 & 0.21 & 0.38 \\
\hline BCPch4 & 0.22 & 0.14 & 0.2 & 0.25 & 0.33 & 0.07 & 0.29 \\
\hline BCPch5 & 0.18 & 0 & 0.21 & 0 & 0.33 & 0 & 0.33 \\
\hline BCPch6 & 0.21 & 0.33 & 0.24 & 0.33 & 0.33 & 0 & 0.33 \\
\hline BCPch7 & 0.23 & 0.17 & 0.19 & 0.12 & 0.42 & 0.08 & 0.33 \\
\hline \multicolumn{8}{|l|}{ Other Controls } \\
\hline Inflation & 0.88 & 0.03 & 2.17 & 0.03 & 0.08 & 0.01 & 0.12 \\
\hline Private Credit per GDP & 29.42 & 2.01 & 56.52 & 115.88 & 0.55 & 2.01 & 0.42 \\
\hline Concentration & 0.56 & 0.5 & 0.21 & 0.68 & 0.56 & 0.42 & 0.73 \\
\hline GDP growth & 0.88 & 0.05 & 2.05 & 1.65 & 0.13 & 0.04 & 0.17 \\
\hline
\end{tabular}

The above variables describe the full sample of 1,146 banks. All bank-level monetary values are deflated to 2005 prices. *These variables have been normalized to take values in the interval $[0,1]$. The normalized variables also have the intuitively appealing property of a percentage interpretation. 
Table 1b: Correlation Matrix of BCP chapter variables

\begin{tabular}{|l|r|r|r|r|r|r|l|}
\hline & \multicolumn{1}{|l|}{ BCPch1 } & BCPch2 & BCPch3 & BCPch4 & BCPch5 & BCPch6 & BCPch7 \\
\hline BCPch1 & 1.00 & & & & & & \\
\hline BCPch2 & 0.71 & 1.00 & & & & & \\
\hline BCPch3 & 0.65 & 0.76 & 1.00 & & & & \\
\hline BCPch4 & 0.68 & 0.78 & 0.84 & 1.00 & & & \\
\hline BCPch5 & 0.70 & 0.75 & 0.71 & 0.73 & 1.00 & & \\
\hline BCPch6 & 0.69 & 0.53 & 0.57 & 0.61 & 0.53 & 1.00 & \\
\hline BCPch7 & 0.64 & 0.59 & 0.70 & 0.68 & 0.58 & 0.54 & 1.00 \\
\hline
\end{tabular}

Given the high correlations between the BCP chapters; the first principal component of each chapter was also used to assess whether bank input efficiency was impacted by sub chapter compliance. The empirical results were broadly similar to those reported in the main findings in Table 3a-3c. 
Table 2: Bank efficiency estimates

\begin{tabular}{|c|c|c|c|}
\hline Panel 1: Full Sample & $\mathrm{EFFbc}$ & SD & $\mathrm{CV}$ \\
\hline All $(n=1146)$ & 0.479 & 0.272 & 0.568 \\
\hline Advanced $(n=241)$ & 0.487 & 0.241 & 0.495 \\
\hline Emerging and Developing $(\mathrm{n}=359)$ & 0.41 & 0.376 & 0.917 \\
\hline Major Advanced $(n=415)$ & 0.567 & 0.262 & 0.462 \\
\hline Transition $(\mathrm{n}=131)$ & 0.454 & 0.268 & 0.590 \\
\hline \multicolumn{4}{|l|}{ Panel 2: Non US Sample } \\
\hline All $(n=850)$ & 0.542 & 0.258 & 0.476 \\
\hline Advanced $(n=243)$ & 0.551 & 0.22 & 0.399 \\
\hline Emerging and Developing $(\mathrm{n}=359)$ & 0.498 & 0.234 & 0.470 \\
\hline Major Advanced $(\mathrm{n}=117)$ & 0.619 & 0.2 & 0.323 \\
\hline Transition $(\mathrm{n}=131)$ & 0.524 & 0.217 & 0.414 \\
\hline \multicolumn{4}{|l|}{ Panel 3: Emerging and Developing Sample } \\
\hline All $(n=359)$ & 0.649 & 0.201 & 0.3097 \\
\hline Central and Eastern Europe (EEU) $(n=7)$ & 0.645 & 0.176 & 0.2729 \\
\hline Centrally planned Asia and China (CPA) $(n=16)$ & 0.75 & 0.136 & 0.1813 \\
\hline Latin America and the Caribbean (LAM) $(n=67)$ & 0.713 & 0.253 & 0.3548 \\
\hline Middle East and North Africa (MEA) $(\mathrm{n}=59)$ & 0.63 & 0.149 & 0.2365 \\
\hline Newly Independent States of FSU (FSU) $(n=8)$ & 0.748 & 0.27 & 0.3610 \\
\hline Other Pacific Asia (PAS) $(n=57)$ & 0.605 & 0.137 & 0.2264 \\
\hline South Asia (SAS) $(n=107)$ & 0.626 & 0.195 & 0.3115 \\
\hline Sub-Saharan Africa (AFR) $(n=28)$ & 0.669 & 0.222 & 0.3318 \\
\hline Western Europe (WEU) $(n=10)$ & 0.514 & 0.257 & 0.5000 \\
\hline
\end{tabular}

EFFbc $=$ Bias-corrected input technical efficiency under variable returns to scaled. This table presents efficiency scores averaged by developmental level and region. The results in all panels were obtained using model 1 . The standard deviation (SD) and the coefficient of variation (CV) are reported for the EFFbc estimates. 
Table 3a: Full Sample Analysis

\begin{tabular}{|c|c|c|c|c|c|c|c|c|}
\hline \multirow{2}{*}{ Predictors } & \multicolumn{4}{|c|}{ Truncated Regression } & \multicolumn{4}{|c|}{ Fractional Logit Regression } \\
\hline & \multicolumn{2}{|c|}{ Baseline } & \multicolumn{2}{|c|}{ Disaggregated } & \multicolumn{2}{|c|}{ Baseline } & \multicolumn{2}{|c|}{ Disaggregated } \\
\hline \multicolumn{9}{|c|}{ Basel Core Principles } \\
\hline BCPscore & -0.0731 & -0.0019 & & & -0.11154 & -0.0234 & & \\
\hline BCPch 1 & & & -0.0127 & -0.0191 & & & -0.077 & -0.1873 \\
\hline BCPch2 & & & 0.044 & 0.0332 & & & 0.431 & 0.2001 \\
\hline BCPch3 & & & 0.0461 & 0.0711 & & & 0.3276 & 0.0832 \\
\hline BCPch4 & & & -0.0258 & -0.0519 & & & -0.2592 & -0.4327 \\
\hline BCPch5 & & & -0.0444 & -0.0045 & & & -0.1325 & -0.2115 \\
\hline BCPch6 & & & -0.0112 & -0.0221 & & & -0.0877 & -0.0673 \\
\hline BCPch7 & & & 0.0457 & 0.009 & & & 0.1325 & 0.0771 \\
\hline \multicolumn{9}{|c|}{ Bank Specific } \\
\hline logta & $0.0113 * *$ & $0.0149 * *$ & $0.0216^{* *}$ & $0.0124 * *$ & $0.0768 * * *$ & $0.0667 * *$ & $0.0887 * * *$ & $0.0776^{* * *}$ \\
\hline lta & $0.315^{* *}$ & $0.1234 * *$ & $0.2315 * *$ & $0.2612 * *$ & $0.0623 * * *$ & $0.0761 * * *$ & $0.569 * * *$ & $0.7322 * * *$ \\
\hline EqTa & -0.0912 & -0.1116 & -0.0178 & -0.0471 & -0.6554 & -0.5477 & -0.2105 & -0.5611 \\
\hline roe & -0.0021 & -0.0021 & -0.0022 & -0.0088 & -0.0241 & -0.0431 & -0.0543 & -0.0521 \\
\hline \multicolumn{9}{|c|}{ Country Specific } \\
\hline infl & $-0.0224 *$ & $-0.1922 * *$ & -0.0165 & -0.1623 & $-0.2097^{*}$ & $-0.8707 *$ & $-0.3321 *$ & $-0.0543 *$ \\
\hline gdpg & $0.138^{* *}$ & 0.0013 & 0.247 & $0.1295^{* *}$ & 0.3214 & $0.2341 * *$ & 0.6752 & 0.5643 \\
\hline PrCrGDP & 0.4312 & $0.3211^{* *}$ & 0.2614 & $0.151 * *$ & 0.1147 & $0.2134 * *$ & $0.2341^{*}$ & $0.3421^{*}$ \\
\hline conc & -0.012 & $-0.3221 * *$ & $-0.0421 *$ & $-0.0331 *$ & -0.1322 & $-0.0431 * * *$ & -0.2665 & -0.1651 \\
\hline caprq & 0.0121 & 0.042 & 0.0331 & 0.0231 & 0.1776 & 0.0165 & 0.0712 & 0.0127 \\
\hline comp & $-0.2193 * *$ & $-0.1087 * *$ & $-0.1412 * *$ & $-0.0977 * *$ & $-0.5477 * *$ & $-0.3341 * *$ & $-0.0156^{*}$ & $-0.032 *$ \\
\hline prmon & $0.1114 * *$ & $0.0812 *$ & $0.1712 * *$ & $0.0696^{*}$ & $0.4501 *$ & $0.2033 * *$ & $0.7012 *$ & $0.554 * *$ \\
\hline depsec & $-0.0568^{*}$ & $-0.1591 * *$ & -0.0313 & -0.0132 & $-0.3192 *$ & $-0.4521^{* *}$ & -0.2112 & -0.032 \\
\hline corpgov & $0.0312 * *$ & 0.0511 & 0.0413 & 0.0543 & 0.1876 & 0.1365 & 0.0912 & 0.1921 \\
\hline restr & -0.0812 & -0.1059 & $-0.0326^{*}$ & $-0.2087 * *$ & -0.1913 & -0.3265 & -0.0431 & $-0.5611^{*}$ \\
\hline \multicolumn{9}{|c|}{ Developmental/Regional dummies } \\
\hline ED & $-0.0213^{*}$ & & $-0.0219 * *$ & & -0.1912 & & -0.1657 & \\
\hline MA & $-0.0940 * *$ & & $-0.1012 * *$ & & -0.114 & & -0.3564 & \\
\hline $\mathrm{T}$ & $-0.0612^{*}$ & & $-0.0141^{*}$ & & -0.0643 & & -0.1612 & \\
\hline CPA & & -0.112 & & -0.0122 & & -0.443 & & -0.3221 \\
\hline EEU & & $-0.124^{*}$ & & -0.029 & & -0.0667 & & -0.0812 \\
\hline LAM & & $-0.0215^{* *}$ & & $-0.0621^{*}$ & & $-0.541^{* *}$ & & $-0.5321^{*}$ \\
\hline MEA & & -0.0238 & & -0.0611 & & -0.2443 & & -0.183 \\
\hline FSU & & -0.0221 & & $-0.019^{*}$ & & -0.0211 & & -0.033 \\
\hline PAS & & -0.1211 & & -0.0114 & & $-0.5611 * *$ & & $-0.3227^{*}$ \\
\hline $\mathrm{PAO}$ & & $0.332 * *$ & & $0.212 * *$ & & $-0.7651 * *$ & & $-0.6658 * *$ \\
\hline SAS & & -0.0121 & & -0.0662 & & -0.0341 & & -0.012 \\
\hline AFR & & -0.0329 & & -0.0511 & & -0.0613 & & -0.1218 \\
\hline WEU & & $0.0992 * *$ & & 0.0771 & & $0.617^{* *}$ & & 0.3114 \\
\hline $\begin{array}{c}\text { Year } \\
\text { dummies } \\
\text { included }\end{array}$ & Yes & Yes & Yes & Yes & Yes & Yes & Yes & Yes \\
\hline Constant & $0.3481 * *$ & $0.2141^{* *}$ & $0.1112 * *$ & $0.0924 * *$ & $0.2123 * *$ & $0.1124 * *$ & $0.0919^{* *}$ & $0.0878 * *$ \\
\hline Obs & 1146 & 1146 & 1146 & 1146 & 850 & 850 & 850 & 850 \\
\hline
\end{tabular}

Dependent variable is EFFbc, $\mathrm{i}, \mathrm{j}=$ the bias-corrected input technical efficiency estimates. ${ }^{* * *} \mathrm{p}<0.01$ Significance from zero at the $1 \%$ level according to bootstrapped confidence intervals, $* * \mathrm{p}<0.05$ Significance at the $5 \%$ level according to bootstrapped confidence intervals, $* \mathrm{p}<0.1$ Significance from zero at the $10 \%$ level according to bootstrapped confidence intervals. 30,000 replications were used to calculate the bootstrapped confidence intervals for the above parameter estimates. For definition os dummy variables see body of text. In the full sample model the benchmark economic group is Advance Economies and the benchmark region is North America, in the no US model the benchmark region is Central \& Eastern Europe. For the fractional logit analysis EFFi, $\mathrm{j}=$ the original uncorrected raw DEA efficiency estimates. 
Table 3b: No U.S. Analysis

\begin{tabular}{|c|c|c|c|c|c|c|c|c|}
\hline \multirow{2}{*}{ Predictors } & \multicolumn{4}{|c|}{ Truncated Regression } & \multicolumn{4}{|c|}{ Fractional Logit Regression } \\
\hline & \multicolumn{2}{|l|}{ Baseline } & \multicolumn{2}{|c|}{ Disaggregated } & \multicolumn{2}{|l|}{ Baseline } & \multicolumn{2}{|c|}{ Disaggregated } \\
\hline \multicolumn{9}{|c|}{ Basel Core Principles } \\
\hline BCPscore & -0.0812 & $\begin{array}{l}-0.0442 \\
-1\end{array}$ & & & -0.1456 & -0.1556 & & \\
\hline BCPch1 & & & -0.105 & -0.0812 & & & $-0.3387^{*}$ & $-0.1097^{*}$ \\
\hline BCPch2 & & & 0.0289 & 0.0043 & & & 0.2651 & 0.0703 \\
\hline BCPch3 & & & 0.0434 & 0.0811 & & & 0.3408 & 0.4407 \\
\hline BCPch4 & & & -0.1123 & -0.2122 & & & -0.0124 & $-0.0933^{*}$ \\
\hline BCPch5 & & & -0.1135 & $\begin{array}{l}-0.0443 \\
\end{array}$ & & & -0.0456 & -0.0891 \\
\hline BCPch6 & & & -0.0332 & $\begin{array}{l}-0.0291 \\
\end{array}$ & & & -0.1533 & -0.0783 \\
\hline BCPch7 & & & 0.0435 & 0.0021 & & & 0.2012 & 0.0912 \\
\hline \multicolumn{9}{|c|}{ Bank Specific } \\
\hline logta & $0.0145^{* *}$ & $0.0219^{* *}$ & $0.0321 * *$ & $0.0221 * *$ & $0.3032^{* *}$ & $0.1277^{* * *}$ & $0.2081 * * *$ & $0.2992 * * *$ \\
\hline lta & $0.0152 *$ & $0.0224 * *$ & 0.0012 & 0.0265 & $0.0442 *$ & $0.0765^{*}$ & $0.0112 * *$ & $0.0881 *$ \\
\hline EqTa & -0.0031 & -0.015 & -0.0112 & $\begin{array}{l}-0.0224 \\
\end{array}$ & $\begin{array}{c}-0.1943 \\
\end{array}$ & -0.2314 & -0.1103 & -0.0945 \\
\hline roe & -0.0332 & -0.0843 & -0.0167 & -0.0181 & -0.0888 & -0.0812 & -0.0934 & -0.0843 \\
\hline \multicolumn{9}{|c|}{ Country Specific } \\
\hline infl & -0.147 & -0.3121 & -0.1014 & -0.2212 & $-0.0332 *$ & $-0.3421 *$ & -0.5611 & -0.2234 \\
\hline gdpg & 0.0355 & 0.0241 & 0.0174 & 0.0478 & 0.2341 & 0.0895 & 0.0345 & 0.1451 \\
\hline PrCrGDP & 0.1232 & 0.2125 & 0.276 & 0.1971 & 0.1556 & 0.0431 & 0.0432 & 0.0954 \\
\hline conc & -0.0214 & $\begin{array}{c}-0.0142 \\
\end{array}$ & -0.043 & -0.051 & $\begin{array}{c}-0.0541 \\
\end{array}$ & -0.0254 & -0.1943 & -0.1642 \\
\hline caprq & 0.044 & 0.0691 & 0.00421 & 0.0453 & 0.0546 & 0.0321 & 0.0541 & 0.0445 \\
\hline comp & -0.0125 & -0.031 & -0.0331 & -0.0321 & $-0.1332^{*}$ & -0.1670 & -0.2134 & -00235 \\
\hline prmon & 0.125 & 0.0431 & 0.0912 & 0.0612 & 0.0995 & 0.0341 & 0.0341 & 0.0991 \\
\hline depsec & $-0.0151^{*}$ & -0.0512 & -0.044 & -0.0215 & -0.0941 & -0.2941 & 0.2112 & -0.0936 \\
\hline corpgov & 0.0775 & 0.0923 & 0.0812 & 0.0912 & 0.2551 & $0.6511^{* *}$ & $0.2432^{*}$ & 0.0176 \\
\hline restr & -0.0472 & -0.0651 & -0.2104 & -0.3122 & $-0.5412^{*}$ & $-0.2126^{* *}$ & $-0.1265^{*}$ & $-0.2177 * *$ \\
\hline \multicolumn{9}{|c|}{ Developmental/Regional dummies } \\
\hline ED & -0.0612 & & -0.0312 & & -0.0725 & & -0.2144 & \\
\hline MA & 0.031 & & 0.032 & & -0.2316 & & 0.1762 & \\
\hline $\mathrm{T}$ & -0.0321 & & -0.061 & & -0.0823 & & -0.0744 & \\
\hline $\mathrm{CPA}$ & & 0.221 & & 0.0132 & & 0.7761 & & $0.6431^{* *}$ \\
\hline LAM & & 0.055 & & $0.034 * *$ & & 0.3241 & & 0.2213 \\
\hline MEA & & 0.0412 & & 0.0611 & & -0.0432 & & -0.0215 \\
\hline FSU & & $-0.0121^{*}$ & & -0.0221 & & $-0.0128 * * *$ & & $0.046^{* *}$ \\
\hline PAS & & 0.0712 & & $0.0182 *$ & & $0.5021^{*}$ & & 0.4215 \\
\hline $\mathrm{PAO}$ & & 0.1143 & & 0.0921 & & 0.0212 & & 0.0401 \\
\hline SAS & & 0.0021 & & 0.0098 & & 0.1761 & & 0.1831 \\
\hline AFR & & 0.0314 & & 0.0512 & & $0.1881^{* *}$ & & $0.4218^{*}$ \\
\hline WEU & & $0.0667 * *$ & & $0.0565^{*}$ & & 0.7761 & & $0.6431 * *$ \\
\hline $\begin{array}{c}\text { Year } \\
\text { dummies } \\
\text { included }\end{array}$ & Yes & Yes & Yes & Yes & Yes & Yes & Yes & Yes \\
\hline Constant & $0.2123 * *$ & $0.1124 * *$ & $0.0919^{* *}$ & $0.0878^{* *}$ & 0.5477 & $0.9981^{*}$ & 0.8019 & $0.8643^{*}$ \\
\hline Obs & 850 & 850 & 850 & 850 & 850 & 850 & 850 & 850 \\
\hline
\end{tabular}

Dependent variable is EFFbc, $\mathrm{i}, \mathrm{j}=$ the bias-corrected input technical efficiency estimates. ${ }^{* * *} \mathrm{p}<0.01$ Significance from zero at the $1 \%$ level according to bootstrapped confidence intervals, $* * \mathrm{p}<0.05$ Significance at the $5 \%$ level according to bootstrapped confidence intervals, ${ }^{*} \mathrm{p}<0.1$ Significance from zero at the $10 \%$ level according to bootstrapped confidence intervals. 30,000 replications were used to calculate the bootstrapped confidence intervals for the above parameter estimates. For definition os dummy variables see body of text. In the full sample model the benchmark economic group is Advance Economies and the benchmark region is North America, in the no US model the benchmark region is Central \& Eastern Europe. For the fractional logit analysis EFFi,j =the original uncorrected raw DEA efficiency estimates. 
Table 3c: Emerging and Developing Countries Analysis

\begin{tabular}{|c|c|c|c|c|c|c|c|c|}
\hline \multicolumn{5}{|c|}{ Truncated Regression } & \multicolumn{4}{|c|}{ Fractional logit Regression } \\
\hline Predictors & \multicolumn{2}{|c|}{ Baseline } & \multicolumn{2}{|c|}{ Disaggregated } & \multicolumn{2}{|c|}{ Baseline } & \multicolumn{2}{|c|}{ Disaggregated } \\
\hline \multicolumn{9}{|c|}{ Basel Core Principles } \\
\hline BCPscore & -0.1211 & -0.0422 & & & -0.166 & -0.4366 & & \\
\hline BCPch1 & & & -0.4113 & -0.1223 & & & $-0.2231^{*}$ & -0.1313 \\
\hline BCPch2 & & & 0.0211 & 0.0321 & & & 0.3321 & $0.3026^{*}$ \\
\hline BCPch3 & & & 0.3211 & 0.1632 & & & 0.4431 & 0.3217 \\
\hline BCPch4 & & & $-0.6112^{*}$ & -0.1224 & & & $-0.5471 * *$ & -0.0221 \\
\hline BCPch5 & & & -0.1432 & -0.1231 & & & -0.4561 & -0.2611 \\
\hline BCPch6 & & & -0.2122 & -0.0178 & & & -0.3411 & -0.2912 \\
\hline BCPch7 & & & $0.4112^{*}$ & 0.2177 & & & $0.2170 * *$ & 0.4316 \\
\hline \multicolumn{9}{|l|}{ Bank Specific } \\
\hline logta & $0.0511 * *$ & $0.0124 * *$ & $0.0421 * *$ & $0.0239 * *$ & $0.3321 * *$ & $0.2518 * *$ & $0.2114 * * *$ & $0.2091 * *$ \\
\hline lta & $0.221 * *$ & $0.132 * *$ & $0.1712 * *$ & $0.0899 * *$ & $0.4431 * *$ & $0.5561 *$ & $0.6651 * *$ & $0.5667 * * *$ \\
\hline EqTa & $0.1812 *$ & $0.1165 * *$ & 0.1774 & $0.3181^{*}$ & 0.9981 & 1.0112 & 0.9234 & $0.7993 *$ \\
\hline roe & -0.0034 & -0.0076 & -0.022 & -0.012 & -0.0421 & -0.0321 & -0.2223 & -0.1334 \\
\hline \multicolumn{9}{|c|}{ Country Specific } \\
\hline infl & -0.6123 & $-0.4356^{*}$ & $-0.1901^{*}$ & $-0.0914^{*}$ & $-0.3314^{*}$ & -0.2387 & $0.1239 * *$ & $-0.3211^{*}$ \\
\hline gdpg & 0.0214 & 0.2113 & 0.7661 & 0.1892 & 0.0671 & 0.0554 & $0.4012 * *$ & $0.3121 *$ \\
\hline PrCrGDP & 0.0124 & 0.0563 & 0.0112 & 0.2131 & $0.0617 * *$ & $0.2112 * *$ & 0.0991 & 0.4311 \\
\hline conc & -0.0321 & -0.0761 & -0.0612 & -0.0134 & $-0.214^{*}$ & $-0.1542 * *$ & -0.0282 & -0.0212 \\
\hline caprq & -0.0321 & -0.0655 & -0.4321 & -0.1376 & -0.1197 & -0.2191 & -0.9321 & -0.4494 \\
\hline comp & -0.0123 & -0.0328 & -0.5417 & -0.0345 & -0.2123 & -0.0184 & $-0.6221 *$ & -0.2501 \\
\hline prmon & 0.0043 & 0.0165 & 0.6782 & 0.0832 & 0.3321 & 0.056 & $0.3016^{*}$ & 0.0321 \\
\hline depsec & -0.0432 & -0.0657 & $-0.211^{*}$ & $-0.3214^{*}$ & -0.8134 & -0.4193 & -0.0912 & -0.813 \\
\hline corpgov & 0.0765 & 0.1455 & 0.3251 & 0.0130 & 0.411 & 0.0328 & 0.5115 & 0.0781 \\
\hline restr & -0.0215 & -0.1321 & -0.7141 & -0.4537 & -0.0541 & -0.221 & $-0.443 *$ & -0.391 \\
\hline \multicolumn{9}{|c|}{ Regional dummies } \\
\hline CPA & & 0.1123 & & 0.3211 & & 0.4431 & & 0.2191 \\
\hline LAM & & -0.1231 & & -0.2112 & & -0.2151 & & -0.4165 \\
\hline MEA & & -0.1112 & & -0.1582 & & -0.2134 & & -0.261 \\
\hline FSU & & 0.0012 & & 0.0045 & & 0.0212 & & 0.0374 \\
\hline PAS & & -0.0238 & & -0.0065 & & -0.0221 & & -0.0186 \\
\hline $\mathrm{PAO}$ & & -0.1276 & & -0.2112 & & -0.3291 & & -0.2556 \\
\hline SAS & & -0.0333 & & -0.0062 & & -0.0849 & & -0.0518 \\
\hline AFR & & -0.0774 & & -0.0828 & & -0.0882 & & -0.0912 \\
\hline WEU & & -0.0327 & & -0.0155 & & -0.0761 & & -0.0221 \\
\hline Year Dummies & Yes & Yes & Yes & Yes & Yes & Yes & Yes & Yes \\
\hline Constant term & 0.2815 & 0.4504 & $1.2641 * *$ & 0.1664 & $-0.1761 * *$ & $-0.7616^{* *}$ & $-0.7711 * *$ & $-0.6651^{*}$ \\
\hline Observations & 359 & 359 & 359 & 359 & 359 & 359 & 359 & 359 \\
\hline
\end{tabular}

Dependent variable is EFFbc, $, \mathrm{i}, \mathrm{j}=$ the bias-corrected input technical efficiency estimates. ${ }^{* * *} \mathrm{p}<0.01$ Significance from zero at the $1 \%$ level according to bootstrapped confidence intervals, $* * \mathrm{p}<0.05$ Significance at the $5 \%$ level according to bootstrapped confidence intervals, $* \mathrm{p}<0.1$ Significance from zero at the $10 \%$ level according to bootstrapped confidence intervals. 30,000 replications were used to calculate the bootstrapped confidence intervals for the above parameter estimates. For definition os dummy variables see body of text. In the full sample model the benchmark economic group is Advance Economies and the benchmark region is North America, in the no US model the benchmark region is Central \& Eastern Europe. For the fractional logit analysis EFFi,j =the original uncorrected raw DEA efficiency estimates. 


\section{APPENDIX}

Table A.1: Full Sample

\begin{tabular}{|c|c|c|c|c|c|}
\hline Country & Number of banks & Year BCP assessment & Country & Number of banks & Year BCP assessment \\
\hline Armenia & 1 & 2005 & Kuwait & 6 & 2003 \\
\hline Australia & 9 & 2005,2012 & Latvia & 2 & 2001 \\
\hline Austria & 7 & 2003,2013 & Lebanon & 3 & 2001 \\
\hline Bahrain & 1 & 2005 & Lithuania & 4 & 2001 \\
\hline Bangladesh & 23 & 2009 & Luxembourg & 2 & 2001 \\
\hline Belgium & 1 & 2013 & Malawi & 2 & 2007 \\
\hline Bolivia & 4 & 2003 & Malaysia & 7 & 2012 \\
\hline Bosnia-Herzegovina & 13 & 2005 & Malta & 4 & 2002 \\
\hline Brazil & 4 & 2012 & Mauritius & 3 & 2002,2007 \\
\hline Chile & 7 & 2003 & Mexico & 9 & 2006,2011 \\
\hline China & 14 & 2011 & Moldova Rep. Of & 8 & 2007 \\
\hline Croatia & 23 & 2001,2007 & Morocco & 5 & 2007 \\
\hline Cyprus & 2 & 2005 & Netherlands & 3 & 2011 \\
\hline Czech Republic & 2 & 2000,2011 & Nigeria & 3 & 2012 \\
\hline Denmark & 15 & 2005,2014 & Oman & 4 & 2003,2011 \\
\hline Ecuador & 6 & 2003 & Panama & 5 & 2001 \\
\hline Egypt & 21 & 2002 & Peru & 9 & 2005,2011 \\
\hline Estonia & 1 & 2000 & Philippines & 17 & 2001 \\
\hline Finland & 2 & 2001 & Poland & 11 & 2000 \\
\hline France & 14 & 2012 & Portugal & 4 & 2005 \\
\hline Germany & 15 & 2003,2011 & Romania & 3 & 2008 \\
\hline Ghana & 4 & 2000 & Russian Federation & 64 & $2002,2008,2011$ \\
\hline Greece & 10 & 2005 & Singapore & 4 & 2002,2013 \\
\hline Guyana & 2 & 2005 & Slovakia & 5 & 2002 \\
\hline Honduras & 13 & 2002,2007 & Slovenia & 1 & 2000 \\
\hline Hong Kong & 7 & 2002,2014 & South Africa & 6 & $2010^{\prime}$ \\
\hline Hungary & 2 & 2000 & Spain & 13 & 2005,2012 \\
\hline India & 70 & 2000,2012 & Sri Lanka & 14 & 2001,2007 \\
\hline Indonesia & 23 & 2000,2010 & Sweden & 6 & 2001,2011 \\
\hline Ireland & 3 & 2014 & Switzerland & 6 & 2001 \\
\hline Israel & 8 & 2000 & Syrian Arab Rep. & 5 & 2008 \\
\hline Italy & 33 & 2003,2013 & Thailand & 10 & 1999 \\
\hline Jamaica & 2 & 2005 & Trinidad \& Tobago & 2 & 2005 \\
\hline Japan & 162 & 2002,2012 & Turkey & 10 & 2011 \\
\hline Jordan & 6 & 2003 & United Kingdom & 8 & 2011 \\
\hline Kenya & 10 & 2003,2009 & Ukraine & 1 & 2002 \\
\hline \multirow[t]{2}{*}{ Korea Rep. Of } & 15 & 2001,2013 & U.S.A & 301 & 2010 \\
\hline & & & Vietnam & 2 & 2013 \\
\hline
\end{tabular}


Table A.2: Summary statistics for original DEA estimates

\begin{tabular}{|c|c|}
\hline Panel 1: Full Sample & Raw DEA Efficiency Scores \\
\hline All $(n=1146)$ & 0.596 \\
\hline Advanced $(n=241)$ & 0.661 \\
\hline Emerging and Developing $(\mathrm{n}=359)$ & 0.531 \\
\hline Major Advanced $(n=415)$ & 0.622 \\
\hline Transition $(\mathrm{n}=131)$ & 0.589 \\
\hline \multicolumn{2}{|l|}{ Panel 2: Non US Sample } \\
\hline All $(n=850)$ & 0.661 \\
\hline Advanced $(n=243)$ & 0.69 \\
\hline Emerging and Developing $(\mathrm{n}=359)$ & 0.612 \\
\hline Major Advanced $(n=117)$ & 0.771 \\
\hline Transition $(\mathrm{n}=131)$ & 0.621 \\
\hline \multicolumn{2}{|l|}{ Panel 2: Emerging and Developing Sample } \\
\hline All $(n=359)$ & 0.789 \\
\hline Central and Eastern Europe (EEU) $(n=7)$ & 0.745 \\
\hline Centrally planned Asia and China (CPA) $(n=16)$ & 0.715 \\
\hline Latin America and the Caribbean (LAM) $(n=67)$ & 0.75 \\
\hline Middle East and North Africa (MEA) $(n=59)$ & 0.69 \\
\hline Newly Independent States of FSU (FSU) $(n=8)$ & 0.791 \\
\hline Other Pacific Asia (PAS) $(n=57)$ & 0.641 \\
\hline South Asia (SAS) $(n=107)$ & 0.701 \\
\hline Sub-Saharan Africa (AFR) $(n=28)$ & 0.667 \\
\hline Western Europe (WEU) $(n=10)$ & 0.66 \\
\hline
\end{tabular}

These are the Original (raw) input technical efficiency estimated under a variable returns to scale assumption. 
Table A.3: Variable definitions

\begin{tabular}{|c|c|c|}
\hline Variables & Definition & Original Source \\
\hline \multicolumn{3}{|c|}{ Financial Intermediation Model } \\
\hline \multicolumn{3}{|l|}{ Bank outputs } \\
\hline Loans & Total loans (mil USD) & Bankscope \\
\hline Other earning assets & Total other earning assets (mil USD) & Bankscope \\
\hline Non-interest income & $\begin{array}{l}\text { Total noninterest income and other fee-based income (mil USD). This measure accounts for } \\
\text { nontraditional banking activities in the financial intermediation process. }\end{array}$ & Bankscope \\
\hline \multicolumn{3}{|c|}{ 19 } \\
\hline $\begin{array}{l}\text { Customer deposits and short term } \\
\text { funding }\end{array}$ & Total customer deposits and short-term funding (mil USD) & Bankscope \\
\hline Total costs & Total of interest and noninterest expenses (mil USD) & Bankscope \\
\hline Equity Capital & $\begin{array}{l}\text { Total Equity (mil USD). This measure is used to adequately capture the impact of risk in the financial } \\
\text { intermediation process. }\end{array}$ & Bankscope \\
\hline \multicolumn{3}{|c|}{ Other Variables } \\
\hline \multicolumn{3}{|c|}{ Dependent variables in regression models } \\
\hline EFFraw,i,j & $\begin{array}{l}\text { Original (raw) DEA input technical efficiency estimates. These scores are calculated in the first step of } \\
\text { our analysis before the application of the Simar and Wilson (2007) double bootstrapping procedure. }\end{array}$ & Authors' calculation \\
\hline EFFbc,i,j & $\begin{array}{l}\text { Bias-corrected DEA input technical efficiency estimates. These scores result from the application of the } \\
\text { first bootstrap of the Simar and Wilson (2007) double bootstrapping procedure on the raw DEA } \\
\text { estimates. }\end{array}$ & Authors' calculation \\
\hline \multicolumn{3}{|c|}{ Macroeconomic and financial conditions variables } \\
\hline (2) & An annual rate of inflation measured as the percentage change in the consumer price index. & World Bank Indicators (WDI) \\
\hline Gdpg & $\begin{array}{l}\text { A measure of the economic conditions under which a bank operates. It is defined as the real annual } \\
\text { growth in GDP. }\end{array}$ & World Bank Indicators (WDI) \\
\hline PrCrGDP & $\begin{array}{l}\text { A ratio of private sector credit to gross domestic product that measures the level of financial } \\
\text { development. }\end{array}$ & World Bank Indicators (WDI) \\
\hline Conc & $\begin{array}{l}\text { A measure of market concentration, which is calculated as the ratio of the assets of three largest banks to } \\
\text { the assets of all publicly traded banks. }\end{array}$ & $\begin{array}{l}\text { Beck, Demirgüç-Kunt and Levine, } \\
\text { (2000), "A New Database on } \\
\text { Financial Development and } \\
\text { Structure," World Bank Economic } \\
\text { Review 14, 597-605. (Dataset } \\
\text { updated April 2013) }\end{array}$ \\
\hline \multicolumn{3}{|l|}{ Regulatory conditions variables } \\
\hline Caprq & $\begin{array}{l}\text { Measures whether capital requirements reflect certain risk elements and deducts certain market value } \\
\text { losses from capital adequacy. It is an index that is the normalized sum of the answers to the following } \\
\text { questions (yes }=1, \mathrm{n}=0 \text { ). (1) Is the minimum required capital asset ratio risk-weighted in line with Basle } \\
\text { guidelines? (2) Does the ratio vary as a function of individual credit risk? (3) Does the ratio vary with } \\
\text { market risk? (4) Before minimum capital adequacy is determined, which of the following are deducted } \\
\text { from the book value of capital: (a) market value of loan losses not realized in accounting books? (b) } \\
\text { Unrealised losses in securities portfolios? (c) Unrealized foreign exchange losses? It takes values } \\
\text { between } 0 \text { and } 1 \text {, with values closer to } 1 \text { indicating greater capital stringency. }\end{array}$ & (Barth, Caprio, and Levine 2012) \\
\hline
\end{tabular}




\begin{tabular}{|c|c|c|}
\hline compj & $\begin{array}{l}\text { Measures the restriction on entry or the lack of competition using the following questions: (1) Limitation } \\
\text { on foreign bank entry/ownership (0-3) lower value indicative of greater stringency; (2) Entry into } \\
\text { banking requirements }(0-8) \text { higher value indicates greater stringency; (3) Percentage of entry } \\
\text { applications denied. An overall index is calculated by normalizing each question to take values between } \\
0 \text { and } 1 \text { and taking an overall average. Values closer to } 1 \text { indicate greater restrictions on } \\
\text { competitiveness. }\end{array}$ & (Barth, Caprio, and Levine 2012) \\
\hline prmonj & $\begin{array}{l}\text { Measures the degree to which banks are required to publicly disclose accurate information and whether } \\
\text { incentives are in place to encourage private monitoring. It is an index that is the normalized sum of the } \\
\text { answers to the following questions. In questions } 1-6: \text { yes }=1 \text { and no }=0 \text { while the opposite occurs in the } \\
\text { case of questions } 7 \text { and } 8 \text { (i.e. yes }=0, \text { no }=1 \text { ). (1) Is subordinated debt allowable (or required) as part of } \\
\text { capital? (2) Are financial institutions required to produce consolidated accounts covering all bank and } \\
\text { any nonbank financial subsidiaries? (3) Are off-balance sheet items disclosed to the public? (4) Must } \\
\text { banks disclose their risk management procedures to public? (5) Are directors legally liable for } \\
\text { erroneous/misleading information? (6) Do regulations require credit ratings for commercial banks? (7) } \\
\text { Does accrued, though unpaid interest/principal enter the income statement while the loan is } \\
\text { nonperforming? (8) Is there an explicit deposit insurance protection system? It takes values between } 0 \\
\text { and } 1 \text {, values closer to } 1 \text { indicate higher levels of private monitoring. }\end{array}$ & (Barth, Caprio, and Levine 2012) \\
\hline depsecj & $\begin{array}{l}\text { This index is calculated as the average of three normalized variables. Each variable is normalized to } \\
\text { take values between zero and one. The variables are: } \\
\text { a) Deposit insurer power: based on the assignment of } 1 \text { (yes) or } 0 \text { (no) values to three questions } \\
\text { assessing whether the deposit insurance authority has the authority: (1) to make the decision to intervene } \\
\text { in a bank, (2) to take legal action against bank directors or officials, or (3) has ever taken any legal action } \\
\text { against bank directors or officers. The sum of the assigned values ranges from } 0 \text { to 3, with higher values } \\
\text { indicating more power. } \\
\text { (b) Deposit insurance funds to total bank assets: the size of the deposit insurance fund relative to total } \\
\text { bank assets. In the case of the U.S. savings and loan debacle during the 1980s, the insurance agency } \\
\text { itself reported insolvency. This severely limited its ability to effectively resolve failed savings and loan } \\
\text { institutions in a timely manner (Barth, 1991). } \\
\text { (c) Moral hazard index: based on Demirgüç-Kunt and Detragiache (2002), who used principal } \\
\text { components to capture the presence and design features of explicit deposit insurance systems, with the } \\
\text { latter including: no coinsurance, foreign currency deposits covered, interbank deposits covered, type of } \\
\text { funding, source of funding, management, membership, and the level of explicit coverage. Higher values } \\
\text { imply greater moral hazard. } \\
\text { Values closer to } 1 \text { indicate higher levels of depositor security. }\end{array}$ & (Barth, Caprio, and Levine 2012) \\
\hline corpgovj & $\begin{array}{l}\text { A measure of corporate governance and quantifies the effectiveness of external audits of banks. It is the } \\
\text { normalized sum of the answers to the following questions (Yes=1, No=0): } 1 \text {.Is an external audit a } \\
\text { compulsory obligation for banks? } 2 \text {. Are specific requirements for the extent or nature of the audit spelled } \\
\text { out? } 3 \text {. Are auditors licensed or certified? } 4 \text {. Do supervisors get a copy of the auditor's report? } 5 \text {. Does } \\
\text { the supervisory agency have the right to meet with external auditors to discuss their report without the } \\
\text { approval of the bank? } 6 \text {. Are auditors required by law to communicate directly to the supervisory agency } \\
\text { any presumed involvement of bank directors or senior managers in illicit activities, fraud, or insider } \\
\text { abuse? } 7 \text {. Can supervisors take legal action against external auditors for negligence? It takes values } \\
\text { between } 0 \text { and } 1 \text {. Values closer to } 1 \text { indicate better strength of external audit. }\end{array}$ & (Barth, Caprio, and Levine 2012) \\
\hline restrj & This measures the extent to which a bank can participate in: (1) securities activities; (2) insurance & (Barth, Caprio, and Levine 2012) \\
\hline
\end{tabular}




\begin{tabular}{|c|c|c|}
\hline & $\begin{array}{l}\text { activities; (3) real estate activities; (4) bank ownership of nonfinancial firms ; (5) Nonfinancial firms } \\
\text { owning banks; and (6) Nonbank financial firms owning banks. These activities can be; unrestricted=1: } \\
\text { full range of activities can be conducted directly in the bank; permitted=2: full range of activities can be } \\
\text { conducted but some must be done within subsidiaries; restricted=3: less than full range of activities can } \\
\text { be conducted in the bank or subsidiaries; and prohibited=4: the activities cannot be conducted in the } \\
\text { bank or subsidiaries. Summing all values and normalizing the result to be between } 0 \text { and } 1 \text { creates an } \\
\text { overall index. Values closer to } 1 \text { indicate greater restrictiveness. }\end{array}$ & \\
\hline BCP compliance variables & $\begin{array}{l}\text { Twenty-five individual compliance rates based on each of } 25 \text { Core Principles are used in the } \\
\text { constructions of the Chapter variables. Each rate is based on a four-point scale: noncompliant }=0 \text {; } \\
\text { materially noncompliant }=1 \text {; largely compliant }=3 \text {; and compliant }=4 \text {. These } 25 \text { are categorized into } \\
\text { seven chapters, which represent different regulatory dimensions of supervision. The seven variables } \\
\text { below represent each of these chapters. }\end{array}$ & $\begin{array}{l}\text { IMF/World Bank Basel Core } \\
\text { Financial Sector Assessment } \\
\text { Program (FSAP) database. }\end{array}$ \\
\hline $\begin{array}{l}\text { BCPCh1 (Chapter 1) } \\
\text { Preconditions for effective } \\
\text { banking supervision }\end{array}$ & $\begin{array}{l}\text { Measures the extent to which the preconditions for effective banking supervision have been met } \\
\text { This index is a normalized sum of the rates of compliance with sub-principles of principle 1: 1(1): There } \\
\text { should be clear responsibilities and objectives set by legislation for each supervisory agency; 1(2): Each } \\
\text { supervisory agency should possess adequate resources to meet the objective set, provided on terms that } \\
\text { do not undermine the autonomy, integrity and independence of supervisory agency; } 1(3) \text { : A suitable } \\
\text { framework of banking laws, setting bank minimum standard, including provisions related to } \\
\text { authorization of banking establishments and their supervision; } 1(4) \text { : The legal framework should provide } \\
\text { power to address compliance with laws as well as safety and soundness concerns; } 1(5) \text { : The legal } \\
\text { framework should provide protection of supervisors for actions taken in good faith in the course of } \\
\text { performing supervisory duties; and } 1(6) \text { : There should be arrangements of interagency cooperation, } \\
\text { including with foreign supervisors, for sharing information and protecting the confidentiality of such } \\
\text { information. This index takes values between } 0 \text { and } 1 \text {, with values closer to } 1 \text { indicative of better } \\
\text { adherence to these preconditions. }\end{array}$ & $\begin{array}{l}\text { IMF/World Bank Basel Core } \\
\text { Financial Sector Assessment } \\
\text { Program (FSAP) database. }\end{array}$ \\
\hline $\begin{array}{l}\text { BCPCh2 (Chapter 2) } \\
\text { Licensing and structure }\end{array}$ & $\begin{array}{l}\text { This index is a normalized sum of the compliance rates of principles } 2-5 ; 2 \text { : Definition of permissible } \\
\text { activities; } 3 \text { : Right to set licensing criteria and reject applications for establishments that do not meet the } \\
\text { standard sets; } 4 \text { : Authority to review and reject proposals for significant ownership changes; and 5: } \\
\text { Authority to establish criteria for reviewing major acquisitions or investments. This index takes values } \\
\text { between } 0 \text { and } 1 \text {, with values closer to } 1 \text { indicative of greater power of supervisors to licence and } \\
\text { influence structure. }\end{array}$ & $\begin{array}{l}\text { IMF/World Bank Basel Core } \\
\text { Financial Sector Assessment } \\
\text { Program (FSAP) database. }\end{array}$ \\
\hline $\begin{array}{l}\text { BCPCh3 (Chapter 3) } \\
\text { Prudential regulation } \\
\text { requirements }\end{array}$ & $\begin{array}{l}\text { Measures the prudence and appropriateness of the minimum capital adequacy requirements that } \\
\text { supervisors set. This index is the normalized sum of the rates of compliance with principles } 6-15: 6 \text { : } \\
\text { Prudent and appropriate risk-adjusted capital adequacy ratios must be set; } 7 \text { : Supervisors should evaluate } \\
\text { banks' credit policies; 8: Banks should adhere to adequate loan evaluation and loan-loss provisioning } \\
\text { policies; 9: Supervisors should set limits to restrict large exposures, and concentration in bank portfolios } \\
\text { should be identifiable; 10: Supervisors must have in place requirements to mitigate the risks associated } \\
\text { with related lending; 11: Policies must be in place to identify, monitor, and control country risks, and to } \\
\text { maintain reserves against such risks; 12: Systems must be in place to accurately measure, monitor, and } \\
\text { adequately control markets risks, and supervisors should have powers to impose limits or capital charge } \\
\text { on such exposures; 13: Banks must have in place a comprehensive risk management process to identify, } \\
\text { measure, monitor, and control all other material risks and, if needed, hold capital against such risks; } 14 \text { : } \\
\text { Banks should have internal control and audit systems in place; and 15: Adequate policies, practices, and } \\
\text { procedures should be in place to promote high ethical and professional standards and prevent the bank }\end{array}$ & $\begin{array}{l}\text { IMF/World Bank Basel Core } \\
\text { Financial Sector Assessment } \\
\text { Program (FSAP) database. }\end{array}$ \\
\hline
\end{tabular}




\begin{tabular}{|c|c|c|}
\hline & $\begin{array}{l}\text { being used by criminal elements. This index takes values between } 0 \text { and } 1 \text {, with values closer to } 1 \\
\text { indicating a greater compliance cost for banks of adherence to the minimum capital requirements. }\end{array}$ & \\
\hline $\begin{array}{l}\text { BCPCh4 (Chapter } 4) \\
\text { Methods of ongoing supervision }\end{array}$ & $\begin{array}{l}\text { This measures the extent of the ongoing supervision. This index is calculated as the normalized sum of } \\
\text { the rates of compliance rates with principles 16-20: 16: An effective supervisory system should consist } \\
\text { of on-site and off-site supervision; 17: Supervisors should have regular contact with bank management; } \\
\text { 18: Supervisors must have a means of collecting, reviewing, and analyzing prudential reports and } \\
\text { statistics returns from banks on a solo and consolidated basis; 19: Supervisors must have a means of } \\
\text { independent validation of supervisory information, either through on-site examinations or use of external } \\
\text { auditors; and 20: Supervisors must have the ability to supervise banking groups on a consolidated basis. } \\
\text { This index takes values between } 0 \text { and 1, with values closer to } 1 \text { indicative of higher levels of on-going } \\
\text { supervision. }\end{array}$ & $\begin{array}{l}\text { IMF/World Bank Basel Core } \\
\text { Financial Sector Assessment } \\
\text { Program (FSAP) database. }\end{array}$ \\
\hline $\begin{array}{l}\text { BCPCh5 (Chapter 5) } \\
\text { Information requirements }\end{array}$ & $\begin{array}{l}\text { A measure of the required extent of a bank's internal financial records. This variable is the normalized } \\
\text { compliance rate for principle } 21 \text { : Each bank must maintain adequate records that enable the supervisor to } \\
\text { obtain a true and fair view of the financial condition of the bank, and must publish on a regular basis } \\
\text { financial statements that fairly reflect its condition. This variable takes values between } 0 \text { and } 1 \text {, with } \\
\text { values closer to } 1 \text { indicative of the increased information requirements placed on banks by supervisors. }\end{array}$ & $\begin{array}{l}\text { IMF/World Bank Basel Core } \\
\text { Financial Sector Assessment } \\
\text { Program (FSAP) database. }\end{array}$ \\
\hline $\begin{array}{l}\text { BCPCh6 (Chapter 6) } \\
\text { Formal Powers of supervisors }\end{array}$ & $\begin{array}{l}\text { A measure of the formal powers of supervisors, calculated as the normalized compliance rate of } \\
\text { principle 22: Adequate supervisory measures must be in place to bring about corrective action when } \\
\text { banks fail to meet prudential requirements when there are regulatory violations, or when depositors are } \\
\text { threatened in any other way. This should include the ability to revoke the banking license or recommend } \\
\text { its revocation. This variable takes values between } 0 \text { and } 1 \text {, with values closer to } 1 \text { indicative of greater } \\
\text { supervisory powers. }\end{array}$ & $\begin{array}{l}\text { IMF/World Bank Basel Core } \\
\text { Financial Sector Assessment } \\
\text { Program (FSAP) database. }\end{array}$ \\
\hline $\begin{array}{l}\text { BCPCh7 (Chapter 7) } \\
\text { Cross-border banking }\end{array}$ & $\begin{array}{l}\text { Measures the extent to which supervisors apply global consolidated supervision over internationally } \\
\text { active banks. This index is calculated as the normalized sum of the compliance rates of principles 23-25: } \\
\text { 23: Supervisors must practice global consolidated supervision over internationally active banks, } \\
\text { adequately monitor, and apply prudential norms to all aspects of the business conducted by these banks; } \\
\text { 24: Consolidated supervision should include establishing contact and information exchange with the } \\
\text { various supervisors involved, primarily host country supervisory authorities; } 25 \text { : Supervisors must } \\
\text { require the local operations of foreign banks to be conducted at the same standards as required of } \\
\text { domestic institutions, and must have powers to share information needed by the home country } \\
\text { supervisors of those banks. This index takes values between } 0 \text { and 1, with values closer to } 1 \text { indicative } \\
\text { of increased practice of global consolidated supervision. }\end{array}$ & $\begin{array}{l}\text { IMF/World Bank Basel Core } \\
\text { Financial Sector Assessment } \\
\text { Program (FSAP) database. }\end{array}$ \\
\hline BCPScore & $\begin{array}{l}\text { An overall index, created by taking the mean value of all seven-chapter indices above. This index takes } \\
\text { values between } 0 \text { and } 1 \text {, with values closer to } 1 \text { indicative of increased overall compliance with the } \\
\text { BCPs. }\end{array}$ & $\begin{array}{l}\text { IMF/World Bank Basel Core } \\
\text { Financial Sector Assessment } \\
\text { Program (FSAP) database. }\end{array}$ \\
\hline
\end{tabular}




\section{ACKNOWLEDGEMENTS}

We are grateful to Mario Catalan (MCM), Pierpaolo Grippa (MCM), Damien Puy (RES), and Natalia Tamirisa (MCD) for their useful comments and feedback. Cecilia Prado and Kia Penso (both from MCD) provided excellent editorial assistance. We also thank Claudia Girardone; Donal McKillop; John O.S. Wilson and participants at the BAFA, Wolpertinger 2014 for valuable comments and discussions on earlier drafts of this paper. 


\section{REFERENCES}

Agoraki, Maria-Eleni K., Manthos D. Delis, and Fotios Pasiouras. 2011. "Regulations, Competition and Bank Risk-Taking in Transition Countries.” Journal of Financial Stability 7(1): 38-48.

Banker, Rajiv D., J. David Cummins, and Paul J M Klumpes. 2010. "Performance Measurement in the Financial Services Sector: Frontier Efficiency Methodologies and Other Innovative Techniques." Journal of Banking \& Finance 34: 1413-16.

Barth, James R, Gerard Caprio, and Ross Levine. 2008. "Bank Regulations Are Changing: For Better or Worse?" Comparative Economic Studies 50(4): 537-63.

Barth, James R., Gerard Caprio, and Ross Levine. 2004. "Bank Regulation and Supervision: What Works Best?” Journal of Financial Intermediation 13(2): 205-48.

Barth, James R., Gerard Caprio, and Ross Levine. 2006. Rethinking Bank Regulation. Till Angels Govern - Cambridge University Press. Second edition. New York: Cambridge University Press.

Barth, James R., Gerard Caprio, and Ross Levine. 2012. Guardians of Finance: Making Regulators Workfor Us. MIT Press.

Barth, James R., Chen Lin, Yue Ma, Jesús Seade, and Frank M. Song. 2013. "Do Bank Regulation, Supervision and Monitoring Enhance or Impede Bank Efficiency?” Journal of Banking \& Finance 37(81): 2879-92.

Barth, James R., Daniel E. Nolle, Triphon Phumiwasana, and Glenn Yago. 2003. “A CrossCountry Analysis of the Bank Supervisory Framework and Bank Performance." Financial Markets, Institutions \& Instruments 12: 205-48. 
Basel Committee on Banking Supervision. 1997. Core Principles for Effective Banking Supervision. https://www.bis.org/publ/bcbs30a.html.

Basel Committee on Banking Supervision. 1999. Core Principles Methodology. http://www.bis.org/publ/bcbs61.htm.

Basel Committee on Banking Supervision. 2006. Core Principles Methodology. http://www.bis.org/Publ/Bcbs130.htm.

Basel Committee on Banking Supervision. 2011a. Consultative Document on Core Principles of Effective Banking Supervision.

Basel Committee on Banking Supervision. 2011b. Core Principles for Effective Banking Supervision.

Basel Committee on Banking Supervision. 2012. Core Principles for Effective Banking Supervision. http://www.bis.org/publ/bcbs230.htm.

Battese, George E., D. S. Prasada Rao, and Christopher J. O’Donnell. 2004. “A Metafrontier Production Function for Estimation of Technical Efficiencies and Technology Gaps for Firms Operating under Different Technologies." Journal of Productivity Analysis, 21: 91-103.

Berger, Allen N. 2007. "International Comparisons of Banking Efficiency." Financial Markets, Institutions \& Instruments 16(3): 119-44.

Berger, Allen N., and Timothy H. Hannan. 1998. "The Efficiency Cost Of Market Power In The Banking Industry: A Test Of The 'Quiet Life' And Related Hypotheses.” The Review of Economics and Statistics 80(3): 454-65.

Bogeoft, Peter, and Lars Otto. 2011. Benchmarking with DEA, SFA, and R. New York: Springer. 
Bos, Jaap W.B., and Heiko Schmeidel. 2007. "Is There a Single Frontier in a Single European Banking Market ?” Journal of Banking \& Finance 31: 2081-2012.

Brissimis, Sophocles N., Manthos D. Delis, and Nikolaos I. Papanikolaou. 2008. "Exploring the Nexus between Banking Sector Reform and Performance: Evidence from Newly Acceded EU Countries." Journal of Banking \& Finance 32(12): 2674-83.

Casu, Barbara, Alessandra Ferrari, and Tianshu Zhao. 2013. "Regulatory Reform and Productivity Change in Indian Banking." The Review of Economics and Statistics 95(3): $1066-77$.

Casu, Barbara, and Philip Molyneux. 2003. "A Comparative Study of Efficiency in European Banking.” Applied Economics 35(17): 1865-76.

Chortareas, Georgios E, Claudia Girardone, and Alexia Ventouri. 2012. "Bank Supervision, Regulation, and Efficiency: Evidence from the European Union.” Journal of Financial Stability 8(4): 292-302.

Cihak, Martin, Asli Demirgüç-Kunt, Maria Soledad Martinez Peria, and Amin MohseniCheraghlou. 2013. "Bank Regulation and Supervision in the Context of the Global Crisis.” Journal of Financial Stability 9(4): 733-46.

Cihak, Martin, Alexander Tienman (2008) "Quality of Financial Sector Regulation and Supervision Around the World" IMF working paper 08/190.

Coelli, T.J., D.S.P Rao, C.J. O’Donnell, and G.E. Battese. 2005. An Introduction to Efficiency and Productivity Analysis. 2nd ed. New: Springer.

Das, Udaibir S., Plamen Iossifov, Richard Podpiera, and Dmitriy Rozkhov. 2005. "Quality of Financial Policies and Financial System Stress.” IMF working paper 05/173. 
Delis, Manthos D., and Nikolaos I. Papanikolaou. 2009. "Determinants of Bank Efficiency: Evidence from a Semi-Parametric Methodology.” Managerial Finance 35(3): 260-75.

Demirgüç-Kunt, Asli, and Enrica Detragiache. 2011. "Basel Core Principles and Bank Soundness: Does Compliance Matter?" Journal of Financial Stability 7(4): 179-90.

Demirgüç-Kunt, Asli, Enrica Detragiache, and Thierry Tressel. 2008. "Banking on the Principles: Compliance with Basel Core Principles and Bank Soundness.” Journal of Financial Intermediation 17(4): 511-42.

Demirgüç-Kunt, Asli, Luc Laeven, and Ross Levine. 2004. "Regulations, Market Structure, Institutions, and the Cost of Financial Intermediation." Journal of Money, Credit and Banking 36: 593-622.

Feldstein, Martin S. 1972. "Equity and Efficiency in Public Sector Pricing: The Optimal TwoPart Tariff." The Quarterly Journal of Economics 86: pp. 175-87.

Fries, Steven, and Anita Taci. 2005. "Cost Efficiency of Banks in Transition: Evidence from 289 Banks in 15 Post-Communist Countries." Journal of Banking \& Finance 29(1): 55-81.

Glass, J. Colin, Donal G. McKillop, and Syamarlah Rasaratnam. 2010. "Irish Credit Unions: Investigating Performance Determinants and the Opportunity Cost of Regulatory Compliance." Journal of Banking \& Finance 34(1): 67-76.

Grigorian, David A, and Vlad Manole. 2006. "Determinants of Commercial Bank Performance in Transition: An Application of Data Envelopment Analysis." Comparative Economic Studies 48(3): 497-522.

Haldane, Andrew. 2013. Constraining Discretion in Bank Regulation. London. http://www.bankofengland.co.uk/publications/Documents/speeches/2013/speech657.pdf. 
Hughes, Joseph P., and Loretta J. Mester. 2010. "Efficiency in Banking: Theory, Practice and Evidence." In The Oxford Handbook of Banking, eds. Alan Berger, Phil Molyneux, and John Wilson. Oxford Handbooks.

Hughes, Joseph P., and Loretta J. Mester. 2013. FRB of Philadelphia Working Paper No. 13-13 Who Said Large Banks Don't Experience Scale Economies? Evidence from a RiskReturn-Driven Cost Function. FRB of Philadelphia Working Paper No. 13-13.

Hughes, Joseph P., and Loretta J. Mester. 2014. "Measuring the Performance of Banks, Theory, Practice, Evidence, and Some Policy Implications.” In Handbook of Banking, eds. John O.S. Wilson, Philip Molyneux, and Allen N. Berger. Oxford University Press, 247-71.

International Monetary Fund. 2014. Review Of The Financial Sector Assessment Program: Further Adaptation To The Post Crisis Era Review Of The Financial Sector Assessment Program - Further Adaptation To The Post-Crisis Era. http://www.imf.org/external/pp/longres.aspx?id=4893.

Kasman, Adnan, and Canan Yildirim. 2006. "Cost and Profit Efficiencies in Transition Banking: The Case of New EU Members." Applied Economics 38(9): 1079-90.

Klomp, Jeroen, and Jakob De Haan. 2012. "Banking risk and regulation: Does one size fit all?." Journal of Banking \& Finance 36: 3197-3212.

Laeven, Luc, and Ross Levine. 2009. Bank Governance, Regulation, and Risk Taking. Journal of Financial Economics 93:259-273.

Leibenstein, Harvey. 1966. "Allocative Efficiency vs. 'X-Efficiency.'” American Economic Review 56(3): 392-415. 
Lozano-Vivas, Ana, and Fotios Pasiouras. 2010. "The Impact of Non-Traditional Activities on the Estimation of Bank Efficiency: International Evidence." Journal of Banking \& Finance 34: 1436-49.

McDonald, John. 2009. "Using Least Squares and Tobit in Second Stage DEA Efficiency Analyses.” European Journal of Operational Research 197(2): 792-98.

Merrouche, Ouarda, and Erlend Nier. 2014. The Global Financial Crisis-What Drove the Buildup ? CEPR Discussion Paper No. 10015.

Papke, Leslie E, and Jeffrey M Wooldridge. 1996. "Econometric Methods for Fractional Response Variables with an Application to 401 ( K ) Plan Participation Rates." Journal of Applied Econometrics 11: 619-32.

Pasiouras, Fotios. 2008. "International Evidence on the Impact of Regulations and Supervision on Banks' Technical Efficiency: An Application of Two-Stage Data Envelopment Analysis." Review of Quantitative Finance and Accounting 30(2): 187-223.

Pasiouras, Fotios, Sailesh Tanna, and Constantin Zopounidis. 2009. “The Impact of Banking Regulations on Banks' Cost and Profit Efficiency: Cross-Country Evidence.” International Review of Financial Analysis 18(5): 294-302.

Podpiera, Richard. 2004. "Does Compliance with Basel Core Principles Bring Measurable Benefits ?" IMF working paper 04/024 53(2).

Sealey, Calvin W., and James T. Lindley. 1977. "Inputs, Outputs, and a Theory of Production and Cost at Depository Financial Institutions." The Journal of Finance 32(4): 1251-66.

Simar, Leopold, and Paul W. Wilson. 2007. "Estimation and Inference in Two-Stage, SemiParametric Models of Production Processes." Journal of Econometrics 136(1): 31-64. 
Sundararajan, V., D. Marston, and R. Basu. 2001. Financial System Standards and Financial Stability - The Case of Basel Core Principles. IMF Working Paper 01/62.

Wilson, Paul W. 1995. "Detecting Influential Observations in Data Envelopment Analysis." Journal of Productivity Analysis 6(1): 27-45. 